Citation details:

Kumar, P., Imam, B. 2013. Footprints of air pollution and changing environment on the sustainability of built infrastructure. Science of the Total Environment 444, 85-101. http://dx.doi.org/10.1016/j.scitotenv.2012.11.056

\title{
Footprints of air pollution and changing environment on the sustainability of built infrastructure
}

3 Prashant Kumar ${ }^{1,2, *}$, Boulent Imam ${ }^{1}$

${ }^{1}$ Department of Civil and Environmental Engineering, Faculty of Engineering and Physical Sciences (FEPS), University of Surrey, Guildford GU2 7XH, UK

${ }^{2}$ Environmental Flow (EnFlo) Research Centre, FEPS, University of Surrey, GU2 7XH, UK

\section{Abstract}

8 Over 150 research articles relating three multi-disciplinary topics (air pollution, climate 9 change and civil engineering structures) are reviewed to examine the footprints of air 10 pollution and changing environment on the sustainability of building and transport 11 structures (referred as built infrastructure). The aim of this review is to synthesize the 12 existing knowledge on this topic, highlight recent advances in our understanding and 13 discuss research priorities. The article begins with the background information on 14 sources and emission trends of global warming $\left(\mathrm{CO}_{2}, \mathrm{CH}_{4}, \mathrm{~N}_{2} \mathrm{O}, \mathrm{CFCs}, \mathrm{SF}_{6}\right)$ and 15 corrosive $\left(\mathrm{SO}_{2}, \mathrm{O}_{3}, \mathrm{NO}_{\mathrm{X}}\right)$ gases and their role in deterioration of building materials (e.g. 16 steel, stone, concrete, brick and wood) exposed in outdoor environments. Further 17 section covers the impacts of climate- and pollution-derived chemical pathways, 18 generally represented by dose-response functions (DRFs), and changing environmental 19 conditions on built infrastructure. The article concludes with the discussions on the 20 topic areas covered and research challenges. A comprehensive inventory of DRFs is compiled. The case study carried out for analysing the inter-comparability of various DRFs on four different materials (carbon steel, limestone, zinc and copper) produced comparable results. Results of another case study revealed that future projected changes in temperature and/or relatively humidity are expected to have a modest effect on the material deterioration rate whereas changes in precipitation were found to show a more dominant impact. Evidences suggest that both changing and extreme environmental conditions are expected to affect the integrity of built infrastructure both in terms of direct structural damage and indirect losses of transport network functionality. Unlike stone and metals, substantially limited information is available on the deterioration of brick, concrete and wooden structures. Further research is warranted to develop more robust and theoretical DRFs for generalising their application, accurately mapping corrosion losses in an area, and costing risk of corrosion damage.

Keywords: Air Pollutants; Built infrastructure; Dose-response functions; Climate change; Green house and corrosive gases; Historic buildings; Transport infrastructure

*Corresponding author: Tel. +44 1483 682762; fax: +44 1483 682135; Email addresses: P.Kumar@surrey.ac.uk, Prashant.Kumar@cantab.net 


\section{Introduction}

Continuous anthropogenic emissions of greenhouse gases (GHG) into the atmosphere have raised the issue of changing climate. This is likely to alter the meteorology and result in important changes such as rise in global temperature, precipitation and sea level, alterations in ground water levels and soil conditions, and increased frequencies of extreme climate events (IPCC, 2007; Isaksen et al., 2009). Consequently, material environment (including buildings and transport infrastructure) is also likely to be affected. In the last decade or so, a large number of studies have studied the impact of climate change on the following key areas: (i) water and its related ecosystems such as storage reservoirs, waterways and irrigation channels, reticulated sewage systems, trunk sewers, treatment plants, storm water drains, flooding, lakes and fisheries (Aaheim et al., 1999; McIlgorm et al., 2010; Vincent and Gene, 2009), (ii) frequency and intensity of rainfall (Ekström et al., 2005), (iii) coastal and river flooding (Booij, 2005; Nicholls, 2004), (iv) power generation and transmission, gas and oil extraction, refining and distribution networks (Söderholm and Pettersson, 2008), (v) settlements and ice glaciers (Nayar, 2009), (vi) air quality and public health (Athanassiadou et al., 2010; Ebi and Burton, 2008; Haines et al., 2006; Vardoulakis and Heaviside, 2012), (vii) transport structures such as roads, railway lines, tunnels, bridges, earthworks, airports, ports, jetties, piers and sea wall protectors (Koetse and Rietveld, 2009; Larsen et al., 2008; TRB, 2008), and (viii) buildings such as historic, residential, commercial, industrial, storage, community and public space facilities (Brimblecombe and Grossi, 2007; Coley and Kershaw, 2010; Karaca, 2012). As illustrated in Fig. 1, the scope of this article is confined to the structural damage of built infrastructure due to the combined effect of climate- and air pollutants-derived chemical pathways and changing environmental conditions. Deterioration and blackening of the historical buildings are very briefly described for the completeness of the article, given that a wealth of published literature currently exists (see Section 3.1.5). In what follows, the term 'built infrastructure' refers to buildings (including heritage) and transport infrastructure (roads, railway tracks, bridges, tunnels, airports, sea ports, earthworks) whereas 'climate-derived parameters' refer to temperature, relative humidity, winds, and precipitation.

Impacts of chemical pathways are seen in terms of deterioration and blackening of building materials. Such impacts are chronic and generally take place over a longperiod of time (see Section 3). Quantification of material loss is generally carried out through the dose-response functions (DRFs) which relate climate parameters with the concentrations of air pollutants (Kucera and Fitz, 1995). The major pollutants used as a variable in DRFs are sulphur dioxide $\left(\mathrm{SO}_{2}\right)$, ozone $\left(\mathrm{O}_{3}\right)$, nitrogen dioxide $\left(\mathrm{NO}_{2}\right)$ and particulate matter (PM) (see Table 1). Past studies have made material loss estimations for varying changes in climate parameters and ambient concentrations of air pollutants 
(Section 3). For example, Screpanti and De Macro (2009) carried out corrosion assessments of cultural heritage buildings in Italy. For limestone and copper, they found the corrosion rates well above the tolerable levels and suggested a need to reduce ambient $\mathrm{O}_{3}$ concentrations in that region. Tidblad (2012) and Ozga et al. (2011) studied air pollution induced atmospheric corrosion of metals in Europe and surface damage to modern concrete buildings, respectively. Likewise, other studies have raised concerns on response of old and cultural heritage buildings due to rapidly changing climate parameters and pollutant concentrations (Brimblecombe and Grossi, 2007; Corvo et al., 2010; Haines et al., 2006; Sabboni et al., 2006; Varotsos et al., 2009).

Changing environmental conditions are another route of damaging the structures and their materials. Such impacts are short-lived, acute and intensive when derived by extreme weather conditions (e.g. more frequent heat waves and extreme rainfall) and long-lived and slow when derived by changing climatic conditions (e.g. increase in the average annual temperature, overall drier summers and wetter winters); such climatic changes have been confirmed by climate models (Hulme et al., 2002; IPCC, 2007; Karl et al., 2009). Both the changes in long-term average climatic conditions and short-term extreme events carry a great potential to affect the sustainability of built infrastructure (see Section 4).

Both the chemical pathways and changing environmental conditions are equally important for the safety and economy of the transport infrastructure. The vast value of transport infrastructure assets shows the risk for large economic losses due to the effects of both climate change and extreme weather conditions. For example, the highway and railway networks in the UK alone have asset values in excess of $£ 87$ and $£ 35$ billion, respectively (Highways Agency, 2009; Network Rail, 2009). Deterioration caused by chemical pathways is likely to be realised over a long-term by increase in the deterioration rate of construction materials such as steel, cast and wrought iron, concrete, masonry and timber. Conversely, extreme environmental conditions can have a significant impact in the short term by disrupting road and rail networks (Booij, 2005; Nicholls, 2004; UNEP, 2007) that can lead to noticeable economic losses (Larsen et al., 2008). In many cases, elements of the transportation infrastructure (e.g. bridge structures) also form part of electricity, telephone, water, gas networks. Therefore, the economic cost of transport asset and network failures may extend far wider than the boundaries of transportation systems to other forms of critical infrastructure (ICE, 2009). For instance, the bridge failures that occurred in Cumbria (UK) in 2009 due to extreme flooding demonstrated the interdependent nature of critical infrastructure where these failures resulted not only in loss of transport connectivity and colossal economic losses but also to failure of telecommunications, gas and electricity supplies (Stimpson, 2009). 
Recent reviews have covered numerous topics such as aviation and ground transport impacts on climate change (Fuglestvedt et al., 2010; Lee et al., 2010) and recent studies have also assessed the impact of climate change on air quality (Athanassiadou et al., 2010), public health (Vardoulakis and Heaviside, 2012), and buildings (Karaca, 2012; McCabe et al., 2011; Ozga et al., 2011). This is the first dedicated review in our knowledge which critically presents the impact of air pollution derived chemical pathways and changing environmental conditions on the built infrastructure. There are five sections in this article. The first section starts with providing the background information on the characteristics of corrosive and GHGs to set the context of the study. This is then followed by a detailed discussion on a relatively less discussed topic: deterioration of building materials by the combined effects of climate parameters and air pollutants. A case study is then presented to demonstrate the inter-variability in results produced by various DRFs and their usefulness in estimating damage to various building materials. The further section discusses the structural and economic impacts caused by the changing environmental conditions. Another case study is included within this section to demonstrate the effect of changing environmental conditions on the material loss of carbon steel (a widely used material in transport infrastructure and structural applications). The last section concludes the topic areas covered and highlights the research gaps and future challenges.

\section{Sources and emission trends of corrosive and GHGs}

This section briefly summarises the sources, emission trends, global warming and corrosive potential of key GHGs (carbon dioxide, $\mathrm{CO}_{2}$; methane, $\mathrm{CH}_{4}$; chlorofluorocarbons, $\mathrm{CFCs}$, and sulphurhexaflouride, $\mathrm{SF}_{6}$, nitrous oxide, $\mathrm{N}_{2} \mathrm{O}$ ) and corrosive gases $\left(\mathrm{SO}_{2}, \mathrm{O}_{3}\right.$ and $\left.\mathrm{NO}_{2}\right)$ for setting up the scene for further discussion and completeness of the article. The GHGs other than the $\mathrm{CO}_{2}$ have relatively less atmospheric concentrations but they carry a much higher global warming potential (see Table 2). All the GHGs included in Table 2 may not directly deteriorate the materials of buildings and transport structures but these contribute indirectly to influence global radiation balance (Jacob and Winner, 2009; Ramanathan and Feng, 2009) and hence the climate parameters and concentrations of corrosive gases via chemical transformation (see Table 1 and Section 3). The mean global concentrations of various GHGs and changes in their concentrations over the past decade are presented in Table 2.

\section{1. $\mathrm{CO}_{2}$}

As seen in Fig. 2, $\mathrm{CO}_{2}$ is the most important GHGs with highest growth rate, largest atmospheric concentrations and substantially longer atmospheric life time. This is mainly produced through consumption of fossil fuels in industries and the transport sector, energy consumption in households, deforestation and natural degradation of biomass sources due to oxidation of carbon compounds in marshes and forests (Climate Change, 2007). Annual emissions of $\mathrm{CO}_{2}$ have grown by $\sim 80 \%$ from 21 to 38 
gigatonnes between 1970 and 2004, representing 77\% of total anthropogenic GHG emissions in 2004 (Climate Change, 2007). Currently, the transportation sector is responsible for a large share (20-25\%) of worldwide man-made $\mathrm{CO}_{2}$ emissions (Fuglestvedt et al., 2008) that could increase to $30-50 \%$ by 2050 (Kumar et al., 2010; Nakicenovic et al., 2000). Besides playing a key role in changing climate parameters (Jacob and Winner, 2009; Ramanathan and Feng, 2009), carbonation caused by atmospheric $\mathrm{CO}_{2}$ to concrete structures is one of the major physicochemical processes (Section 3.1.2) which can compromise the service life of reinforced concrete structures such as buildings and bridges (Peter et al., 2008; Tonoli et al., 2010).

\section{2. $\mathrm{CH}_{4}$}

$\mathrm{CH}_{4}$ has the second greatest effect on global climate after $\mathrm{CO}_{2}$ (Table 2). Main sources of $\mathrm{CH}_{4}$ includes anaerobic degradation of organic matter in rice fields, natural wet lands, landfills, digestive tract of cattle, production and use of oil and natural gas and incomplete burning of organic material. The global atmospheric concentration of $\mathrm{CH}_{4}$ has increased over 2-fold from a pre-industrial value of about 715ppb to 1732ppb in the early 1990s, and to $1774 \mathrm{ppb}$ in 2005 , mainly due to increased agricultural activities and fossil fuel use (Climate Change, 2007). Like $\mathrm{CO}_{2}, \mathrm{CH}_{4}$ does not corrode the material directly, but influences the chemistry of $\mathrm{O}_{3}$ (Section 2.8) which is one of the most corrosive gases and the climate parameters through radiative forcing.

\section{3. $\mathrm{N}_{2} \mathrm{O}$}

$\mathrm{N}_{2} \mathrm{O}$ is the fourth largest single contributor to positive radiative forcing, and serves as the long lived atmospheric tracer of the human perturbations of the global nitrogen cycle (IPCC, 2007). This is produced from the burning of biomass and nitrogen rich fuels (especially coal), break down of nitrogen fertilisers in soil, livestock wastes and nitrate contaminated ground water. The global atmospheric $\mathrm{N}_{2} \mathrm{O}$ concentration increased from a pre-industrial value of about 270ppb to 319ppb in 2005, and a further increase by $35-50 \%$ up to 2030 is expected due to increased nitrogen fertilizer use and increased animal manure production (Climate Change, 2007). The $\mathrm{N}_{2} \mathrm{O}$ does not contribute to material corrosion directly, but its positive contribution to radiative forcing influences the environmental conditions.

\subsection{CFCs}

CFCs contribute to global warming by absorbing long-wave radiation (Fisher et al., 1990). These come into the environment through leaking air conditioners, refrigerators, evaporation of industrial solvents, production of plastic foams, aerosols and propellants. Their global mean atmospheric concentrations have increased from a near-zero pre-industrial background to about $251 \mathrm{ppt}$ (CFC-11), $538 \mathrm{ppt}$ (CFC-12) and 78 ppt (CFC-113) in 2005 (IPCC, 2007). When ultraviolet radiation strikes the CFCs molecules, carbon-chlorine bond is broken and chlorine atoms are produced. A single 
chlorine atom in the stratosphere can destroy 100,000 molecules of $\mathrm{O}_{3}$ over its natural lifetime. Thus the CFCs play a crucial role for changing the radiation balance and hence the climate parameters.

\section{5. $\mathrm{SF}_{6}$}

$\mathrm{SF}_{6}$ is an extremely stable atmospheric trace gas that is produced entirely through anthropogenic emissions. About $80 \%$ of the $\mathrm{SF}_{6}$ produced worldwide is used in and released from electrical equipment, predominantly from gas insulated switchgear (Maiss et al., 1996). $\mathrm{SF}_{6}$ emissions are also one of the six GHGs targeted for reduction under the Kyoto Protocol. Studies show an increase in mixing ratios from near zero in the 1970s to a global mean value of $4.1 \mathrm{ppt}$ in 1998 (IPCC, 2007) and $6.3 \mathrm{ppt}$ by the end of 2007 (Levin et al., 2009), showing about 54\% increase in 2007 over the 1998 levels. In our context, the role of $\mathrm{SF}_{6}$ is in the form of influencing the climate parameters through disturbing the radiation balance.

\section{6. $\mathrm{SO}_{2}$}

$\mathrm{SO}_{2}$ is predominantly produced through sulphur-led anthropogenic activities occurring in industries (e.g. power generation using coal in refineries, cement, brick and ceramic), through waste incineration, road transport emissions and mineral processing like the ferrous metal production (Ramanathan and Feng, 2009). $\mathrm{SO}_{2}$ shows cooling effects on climate in low or moderate emission conditions (Ward, 2009), but it is crucial for deteriorating the materials used in buildings and transport infrastructure (see Section 3). $\mathrm{SO}_{2}$ in the atmosphere is oxidised to particle phase and gas species after reactions with other atmospheric species, which then further oxidised to its acid forms (e.g. sulphurous acid, $\mathrm{H}_{2} \mathrm{SO}_{3}$, sulphuric acid, $\mathrm{H}_{2} \mathrm{SO}_{4}$ ) on the surface of materials. These acids react with the building materials to damage them. Corrosion impacts of $\mathrm{SO}_{2}$ are greatly influenced by the temperature and relative humidity. For example, Noah's Ark (2006) reported that corrosion of materials is expected to increase in the Northern part of the Europe and to decrease in the southern part even if atmospheric levels of $\mathrm{SO}_{2}$ remain constant. Emissions of acidic air pollutants such as the $\mathrm{SO}_{2}$ are likely to decrease in future in many parts of the world, most certainly in European countries, as a consequence of stricter regulations (Brimblecombe and Grossi, 2007). This is likely to lead to an overall improvement in deterioration rates of various materials attributed to acid deposition. More precisely, current observations reveal a continuous decrease by $70-90 \%$ in $\mathrm{SO}_{2}$ emissions since the 1970s in Europe, following a series of control measures such as the decreasing sulphur contents in diesel fuel and implementation of air pollution control measures in power plants (Fowler et al., 2007). A recent study by Kuribayashi et al. (2012) summarised the long-term trends of $\mathrm{SO}_{2}$ emissions and deposition in East Asia, indicating contrasting trends to those reported for European environments. For example, China accounts for $64-71 \%$ of the total Asian $\mathrm{SO}_{2}$ emissions; a rapid increase in its emissions were noted between 1980s to the mid-1990s, 
9-17\% decrease between 1996 and 2000, and again a sudden increase of about 61\% between 2000 and 2006, followed by a 9.2\% decrease during 2006-2010 (Lu et al., 2011). As opposed to China, India's national emissions of $\mathrm{SO}_{2}$ have increased by $70 \%$ in $2010(8.8 \mathrm{Tg})$ from the 1996 levels $(5.2 \mathrm{Tg})$ and the current emission trend is upward (Lu et al., 2011).

\section{7. $\mathrm{NO}_{\mathrm{x}}$}

$\mathrm{NO}_{\mathrm{x}}$ is generally taken as the sum of $\mathrm{NO}$ and $\mathrm{NO}_{2}$. This is a corrosive gas which is oxidised to its acid form (e.g. nitrous acid, $\mathrm{HNO}_{2}$, nitric acid, $\mathrm{HNO}_{3}$ ) on the surfaces of materials. These acids are responsible to much of the damage to building materials (Section 3.1.1). This also play an important role in the formation of tropospheric $\mathrm{O}_{3}$ (Lewne et al., 2004; Nagpure et al., 2011). A dominant fraction of $\mathrm{NO}_{\mathrm{x}}$ is produced from the combustion activities at high temperatures, such as in engines of motor vehicles. The situation of $\mathrm{NO}_{\mathrm{x}}$ emissions in Europe is different to those in, for example, Asia or Latin America where the emissions are appearing to be increasing due to lessstringent policy regulations (Vestreng et al., 2009). Recent studies have found a significant decrease in $\mathrm{NO}_{\mathrm{x}}$ concentrations in compliance with the EU standards and directives at roadside sites in Europe (Mavroidis and Chaloulakou, 2011). This decrease is, though, not as fast as foreseen by the directives regulating vehicle emissions. Despite the overall $\mathrm{NO}_{\mathrm{x}}$ reductions in Europe, a corresponding decrease in the ambient $\mathrm{NO}_{2}$ concentrations has not yielded and its exceedances over the limit values are being reported in many urban locations across Europe (Mavroidis and Chaloulakou, 2011). This is primarily due to significant increase in the $\mathrm{NO}_{2} / \mathrm{NO}_{\mathrm{x}}$ ratio, highly non-linear dependency of secondary $\mathrm{NO}_{2}$ (contributing $~ 70 \%$ of total) on $\mathrm{NOx}$, and the increasing $\mathrm{NO}_{2}$ ratio in late diesel engine technology vehicles (Vestreng et al., 2009). However, ever growing stricter emission standards in Europe and both the in-cylinder and aftertreatment control measures are likely to bring reduction in $\mathrm{NOx}$ and primary $\mathrm{NO}_{2}$ emissions in future.

\section{8. $\mathrm{O}_{3}$}

$\mathrm{O}_{3}$ is a secondary pollutant and its concentrations depend on the atmospheric chemistry and emissions of its anthropogenic precursors (e.g. NOx, $\mathrm{CO}, \mathrm{CH}_{4}$ and volatile organic compounds, VOCs) that originate from fossil fuel combustion and natural sources such as vegetation. The $\mathrm{O}_{3}$ is generated through the photochemical oxidation of its precursors by the hydroxyl radical $(\mathrm{OH})$ in the presence of reactive NOx (Jacob and Winner, 2009). OH radicals are formed through atmospheric oxidation of water vapour and cycles in the atmosphere with other hydrogen oxide radicals. The sources of $\mathrm{O}_{3}$ precursors are generally located in the boundary layer where the lifetime of $\mathrm{O}_{3}$ is of the order of days (Jonson et al., 2005; Nagpure et al., 2011). Major sinks of ground-level $\mathrm{O}_{3}$ are dry deposition on vegetation and photolysis which occurs in the presence of water vapour (Jacob and Winner, 2009). $\mathrm{O}_{3}$ is a powerful oxidiser which 
exerts a direct corrosive effect on various materials that are even measurable at as low as $20 \mathrm{ppb}$ atmospheric concentrations (CC Report, 2003). Despite reductions in the emissions of $\mathrm{O}_{3}$ precursors, predictions associated with global climate change have shown that ground-level $\mathrm{O}_{3}$ concentrations are expected to increase in future years (Zeng et al., 2010). For example, background concentrations of ground-level $\mathrm{O}_{3}$ in northern mid-latitudes have almost doubled to $35-40 \mathrm{ppb}$ since the $19^{\text {th }}$ century; anthropogenic emissions contribute half to two third of these emissions (Garthwaite et al., 2009). At the same time, recent studies also conclude that magnitude and origin of ground-level $\mathrm{O}_{3}$ trends in Europe are not completely understood, and that the local trends can be dominated by the changes in emissions of $\mathrm{O}_{3}$ precursors (Jonson et al., 2005). $\mathrm{O}_{3}$ concentrations in the atmospheric boundary layer result in continuous oxidation of polymers and building materials used in modern construction, and may also enhance the production of acids after reacting with $\mathrm{SO}_{2}$ and $\mathrm{NO}_{\mathrm{x}}$ (Brimblecombe and Grossi, 2007). As discussed in Section 3, numerous studies have reported impact of ground-level $\mathrm{O}_{3}$ on various building materials and its increasing importance in future years (CC Report, 2003; Noah's Ark, 2006; Prather et al., 2003; Screpanti and De Marco, 2009).

\section{Chemical pathways: material deterioration of built infrastructure}

This section firstly describes the chemical sensitivity of materials used in the built infrastructure. This is then followed by a comprehensive review of available DRFs which are presented in Table 3. Further section assesses the practical applications and limitations of the DRFs with the help of a case study.

\subsection{Chemical sensitivity of various building materials}

Atmospheric corrosion of materials is a cumulative and irreversible process that may occur even in the absence of air pollutants (Helcher et al., 1991). Structures are predominantly made of steel, concrete, brick masonry, stone and wood materials and have particular sensitivity towards various chemical processes as described below.

\subsubsection{Oxidation sensitive materials}

Steel and stone materials are largely influenced by oxidation processes led by $\mathrm{SO}_{2}$, NOx and $\mathrm{O}_{3}$ (see Table 3). The $\mathrm{SO}_{2}$ can deposit on the surface of materials and oxidise into $\mathrm{SO}_{4}$ (Corvo et al., 2010). After reacting with the water droplets present in the atmosphere, this then forms $\mathrm{H}_{2} \mathrm{SO}_{4}$ which corrodes these materials by coming in contact through rain (Livingstone, 1992). $\mathrm{NO}_{\mathrm{x}}$ has similar characteristics to form $\mathrm{HNO}_{3}$ at the surface of the material and within the atmosphere to affect these materials. $\mathrm{O}_{3}$ is a powerful oxidiser and its effect on steel and stone is measurable even at very low (20 ppb) atmospheric concentrations (CC Report, 2003). A study by Lee et al. (1996) assessed the potential damage by $\mathrm{O}_{3}$ to the materials in the UK as $£ 170-£ 345$ million $\mathrm{yr}^{-1}$. This includes damage to surface coatings and elastomers, and the cost of anti- 
ozonant protection applied to rubber goods. The effects of $\mathrm{O}_{3}$ on the costs of repainting were estimated in the range of $£ 0-£ 60$ and $£ 0-£ 182$ million $\mathrm{yr}^{-1}$ for a change in $\mathrm{O}_{3}$ from 15 to $20 \mathrm{ppb}$ and 15 to $30 \mathrm{ppb}$, respectively.

\subsubsection{Carbonation sensitive materials}

Plain or reinforced concrete is semi impermeable, one of the oldest, most durable, widely used composite, but a carbonation sensitive building material. Past studies have examined qualitative impacts of air pollution and changing environmental conditions on reinforced concrete deterioration but methods for quantitative estimations are still an open area for research (Ozga et al., 2011). At present, there are no DRFs available for concrete, clearly because it is not a single material but a composite. Reinforced concrete is affected by chloride attack, $\mathrm{CO}_{2}$-induced carbonation and freeze-thaw (thermal shocks) processes, mainly caused by climate parameters (Jacobsen et al., 1995; Shang et al., 2009). While high presence of waterborne salts, particularly chloride ions, initiates the chloride attack to reinforcement, carbonation is characterised by the introduction of factors that destroy the protective passive layer of reinforcement. This passivating environment for the reinforcement is destroyed by multi-pollutants, derived mainly by oil and coal combustion processes, such as $\mathrm{NO}_{\mathrm{X} /} \mathrm{HNO}_{3} \cdot \mathrm{CO}_{2} / \mathrm{H}_{2} \mathrm{CO}_{3}$ (carbonation), or $\mathrm{SO}_{2} / \mathrm{H}_{2} \mathrm{SO}_{4}$ (sulphation) (Ozga et al., 2011). The latter influences the alkalinity of concrete and converts calcium aluminate into ettringite and gypsum $\left(\mathrm{CaSO}_{4} \cdot 2 \mathrm{H}_{2} \mathrm{O}\right)$, and the gypsum thus formed occupies a larger volume than the original concrete and lead to surface deterioration. This is an important damage process to affect concrete structures in $\mathrm{SO}_{2}$ rich urban environments (Marinoni et al., 2003). This is particularly the case with cities in developing countries (e.g. India; see Section 2.6) where $\mathrm{SO}_{2}$ levels are yet increasing compared with decreasing $\mathrm{SO}_{2}$ emission trends in European and North American cities, mainly due to declining sulphur contents in diesel fuel (Lu et al., 2011; Kuribayashi et al., 2012; Stern, 2005; Kumar et al., 2011). Likewise, atmospheric $\mathrm{CO}_{2}$ diffuses through the unsaturated concrete pores, reacts with carbon solutes and then forms a mildly acidic solution (Peter et al., 2008). This results in a drop in $\mathrm{pH}$ value of inside concrete environment from about 13. When this goes below about 10.5, carbonation starts to erode the concrete material and exposes the reinforcing steel within it. Similar principle applies to plain concrete structures. External facades of these structures are particularly vulnerable to such phenomena because of increased susceptibility of the condensation of water. However, plain concrete material is more resistant, due to the absence of reinforcement, which is more sensitive to corrosion; carbonation for instance is not such a serious problem as in the case of reinforced concrete.

Peng and Stewart (2008) analysed the impacts of increasing concentrations of $\mathrm{CO}_{2}$ on carbonation of reinforced concrete. They concluded that the effect of carbonation is much higher on high water-cement (w/c) ratio concrete as opposed to low w/c ratio 
concrete, with distance between carbonation front and reinforced steel bar being a key. They also developed a method for time dependent reliability analysis to calculate probabilities of corrosion initiation, mean proportions of corrosion damage and probabilities of structural collapse when the $\mathrm{CO}_{2}$ concentration increases with time over the next 100 years. They found that probability of corrosion initiation to reinforced concrete structures can be up to $720 \%$ higher than a scenario based on maximum mitigation of $\mathrm{CO}_{2}$ emissions. The worst emissions scenario increased the likelihood and extent of corrosion damage by $540 \%$ when compared to the structural reliability for the best mitigation scenario (Peng and Stewart, 2008). Other studies have also proposed diffusion models for carbonation (CEB, 1997; Kersner et al., 1996) and found their modelled results most sensitive to increase in atmospheric $\mathrm{CO}_{2}$ (Stewart et al., 2011). Detailed investigation of these models is out of the scope of our review, but further information on this topic can be found in Papadakis et al. (1992), Yoon et al. (2007), Peter et al. (2008), Bastidas-Arteaga et al. (2010), Stewart et al. (2011), and references therein.

\subsubsection{Soiling / weathering sensitive materials}

Similar to stone, brick material is prone to weathering or soiling process. The process is caused by changing environmental conditions such as the variations in temperature and relative humidity, wind speed, freezing and thawing, extraction by rain and snow melt water, acid rain and microbial activities (Hirsch et al., 1995). Acid rain is one of the most prominent chemical deterioration processes for brick masonry structures because of: (i) the susceptibility of bricks to acid rain through the selective dissolution of their glassy phase, (ii) the reactions within the calcareous components of mortar affecting its strength, and (iii) migration of soluble salts resulting from the above reactions (within the solution with rain water or condensed moisture) through the porous matrix of the masonry, and finally (iv) evaporation of water leaving salt deposited on the brick surfaces and such repeated dissolution and recrystallisation leading to the mechanical disruption of the masonry structure (Charola and Lazzarini, 1986). Other important mechanisms are frost and freeze-thaw actions, but these are mainly derived by extreme or changed environmental conditions (Kvande and Lis $\varnothing$, 2009; Nijland et al., 2009). Rather limited information is available on brick material and future investigations are needed to analyse the detailed impacts of changing climate and air pollutants on such structures.

\subsubsection{Moisture sensitive materials}

Little is known about the deterioration of wood or timber through airborne chemical species. There are however evidences relating their deterioration with climate parameters, mainly atmospheric moisture. The principal mechanism for damaging such open-air structures is attack by wood pests, especially fungi (Herlyn and Mehlhorn, 1999; Nijland et al., 2009). Chances of fungal attacks are even more in high 
precipitation areas. This process is mainly driven by moisture penetration to woods and ambient temperature, and is generally estimated through 'Scheffer Climate Index (SCI)'. The higher the SCI the greater is the decay hazard i.e. >65 (severe), 35-65 (moderate) (Scheffer, 1971). Fungal growth starts occurring when moisture penetration goes past the critical value which is $\sim 20 \%$ as estimated by Noah's Ark (2006). Woodinhabiting fungi may grow in a temperature range of about $+3{ }^{\circ} \mathrm{C}$ to about $+40{ }^{\circ} \mathrm{C}$ with an optimum temperature of about $+25^{\circ} \mathrm{C}$ (Hof, 1981). The Noah's Ark (2006) report concluded that wood deterioration due to fungal growth can increase up to $100 \%$ in high precipitation areas (e.g. Scandinavian countries and Northern Russia). A recent study by Brischke and Rapp (2008) established DRFs for Scots pine sapwood and Douglas fir heartwood for up to 7 years exposure in 27 different European test sites. They found that a traditional ' $\mathrm{SCI}$ ' is not an appropriate tool for estimating site specific decay potential of woods. Rather, they established DRFs, predominantly based on moisture content and wood temperature, for predicting service life of woods (see Table 3). However, these results were for a limited set of experimental conditions and detailed studies establishing relationship between moisture content and the amount and duration of rainfall under different exposure situation are still required (Brischke and Rapp, 2008). Furthermore, there are currently a negligible number of studies available relating wood deterioration with both climate parameters and air pollutants. Such studies are needed to better understand this problem.

Another type of material, which is sensitive to moisture-induced deterioration, is Fibre Reinforced Polymer (FRP) composites, used widely for strengthening as well as for the construction of light-weight structures. Absorption of moisture leads to hydrolysis, plasticization and saponification on the resin which may cause irreversible changes in the polymer structure and loss of integrity of the fibre-matrix structure. The polymer matrix present in composite materials is also prone to degradation initiated by ultraviolet (UV) radiation, temperature and high $\mathrm{pH}$ environments (Chin et al., 1997). Exposure to sub-zero temperatures can result in matrix hardening, micro-cracking and degradation and freeze-thaw cycles can lead to accelerated degradation of the material. Exposure to UV radiation leads to surface deterioration which adversely affects mechanical properties and can increase moisture ingress in the deteriorated regions. Although the effect of environmental conditions on the durability of composite materials are qualitatively known, as discussed above, actual data on the durability of composite materials is sparse due to the lack of long-term experiments to different types of atmospheric and environmental conditions (Karbhari et al., 2003).

\subsubsection{Deterioration and blackening of buildings}

Of the notable research efforts carried out in recent years on this topic has been the work by Brimblecombe, Grossi, McCabe and their co-workers, besides the researchers from the ICP projects (Tidblad et al., 2001), Noah's Ark (2006) and 
MULTI-ASSESS (Kucera et al., 2007). The impact of changing environment on buildings can occur in the form of deterioration and blackening of building stones, driven by processes such as freeze-thaw cycles, wind driven rain, humidity cycles and salts, gas and particle concentrations, $\mathrm{pH}$ of precipitation, and the water table level (Brimblecombe and Grossi, 2007; Karaca, 2012; Ozga et al., 2011). Blackening of buildings materials due to accumulation of PM containing dark elemental carbon is a common problem (Haynie, 1986). Grossi et al. (2008) concluded that recession rates of architectural limestone buildings in European cities will remain largely unchanged over the coming century due to the continuously declining level of air pollutants despite the changes in climate parameters. However, a dramatic change can occur in blackening pattern of buildings due to new climate regimes and a somewhat different trend may emerge. For instance, reduced emissions of PM and increase in seasonal rainfall may help in self-cleaning of buildings, but probably at the expense of encouraging microorganisms growth that may result in yellowing of buildings (Noah's Ark, 2006). Recent studies have also indicated the biological greening of natural stone buildings. The predominant reasons quoted for such effects is algal growth in response to wetter exposure conditions, possibly in combination with reduced atmospheric $\mathrm{SO}_{2}$ and an increase in atmospheric nitrogen $\left(\mathrm{NO}_{\mathrm{X}}\right)$ from vehicular pollution at some locations (McCabe et al., 2011). A wealth of literature is available on the impacts of climate change on natural building stones and therefore is covered here briefly for the completeness of the article.

\subsection{DRFs}

Atmospheric pollutants influence the global climate by regulating the radiation budget (Isaksen et al., 2009) and act together with a range of climate parameters to damage the building materials (Texte 24/99, 1999). The DRFs serve as a tool to quantitatively assess material damage by combining both the climate parameters and pollutant concentrations using the general expression as shown in Eq. (1) (Kucera and Fitz, 1995; Tidblad, 2007; Tidblad et al., 2001):

$$
\mathrm{ML}=f_{\text {dry }}(\mathrm{T}, \mathrm{Rh},[\mathrm{GHG} \text { and corrosive gases }]) \times t^{\mathrm{m}}+f_{\text {wet }}(\mathrm{Rn},[\text { ions }]) \times t^{\mathrm{n}}
$$

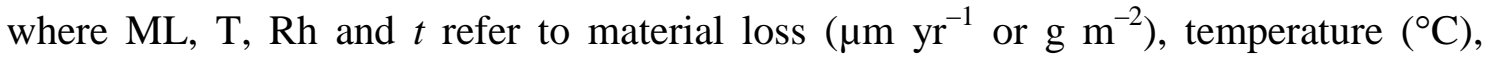
relative humidity (\%) and exposure duration (year), respectively. $\mathrm{Rn}$ is precipitation (m $\left.\mathrm{yr}^{-1}\right)$; ions are concentrations of $\left[\mathrm{H}^{+}\right]$that are derived from the $\mathrm{pH}$ of rain; $m$ and $n$ are empirical constants. The first part of Eq. (1) indicates material loss due to dry corrosion while the second part refers to wet corrosion. The above expression is modified by numerous authors for establishing a number of empirical relationships presented in Table 3.

As seen from the DRFs in Table 3, $\mathrm{SO}_{2}$ and $\mathrm{O}_{3}$ are important corrosive gases. $\mathrm{SO}_{2}$ shows a non-linear relationship (exponent generally less than unity) with corrosion and 
its corrosive effect is maximum at a temperature of about $9-11^{\circ} \mathrm{C}$ (Kucera et al., 2007). Although, $\mathrm{SO}_{2}$ is no longer a dominant pollutant in most parts of the developed world, concentrations of ground-level $\mathrm{O}_{3}$ still remain a major concern (see Sections 2.6 and 2.8). Relative humidity, $\mathrm{H}^{+}$ions in rain and temperature are important for corroding most metals while $\mathrm{Cl}^{-}$deposition plays an important role in corroding carbon steel, aluminium and cast bronze (Table 3). It should be noted that concrete is not included in the listed materials due to the lack of available DRFs.

New versions of international standards have recently been published (BS EN ISO 9223, 2012; BS EN ISO 9224, 2012) for classifying, determining and estimating the corrosivity of metals and alloys. These standards are widely adopted throughout the world for the purposes of corrosion assessment of materials. BS EN ISO 9223 (2012) provides DRFs for calculating the first-year corrosion rate of carbon steel, zinc, copper and aluminium materials; their summary is presented in Table 4. The ISO-proposed DRFs are based on the previous research and hence show a similar form to those listed in Table 3 (i.e. material loss is a function of atmospheric pollutant concentrations and climate parameters).

For long-term estimation of corrosion loss, the effect of changes in atmospheric pollutant concentrations as well as in environmental conditions (climate parameters) is needed to be taken into account. BS EN ISO 9224 (2012) provides such relationships for estimating the total corrosion loss, $D(\mu \mathrm{m})$, of various metals:

$$
\begin{array}{lr}
D=r_{\text {corr }} t^{b} & \text { for } \mathrm{t}<20 \text { years } \\
D=r_{\text {corr }}\left[20^{b}+b\left(20^{b-1}\right)(t-20)\right] & \text { for } \mathrm{t}>20 \text { years }
\end{array}
$$

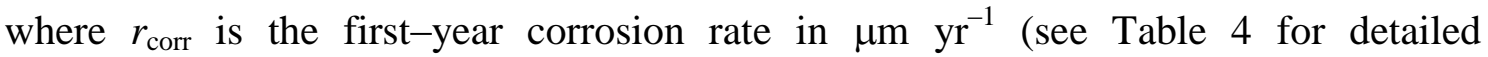
expressions), $t$ is the exposure time in years, and $b$ is a metal-environment-specific time exponent (i.e. $b=0.523$ for carbon steel; $b=0.813$ for zinc, $b=0.667$ for copper, $b=0.728$ for aluminium). By looking at Eq. (2) and (3), it can be seen that changes in atmospheric pollutant concentrations and climate parameters can only be captured through the first-year corrosion rate, $r_{\text {corr }}$. Therefore, it can be argued that the BS EN ISO 9224 (2012) functions are not well-suited for taking into account gradual changes of the above parameters over time.

\subsubsection{Case study for analysing the inter-comparability of DRFs}

For analysing the inter-comparability of various DRFs, a case study is conducted on 4 different materials (limestone, carbon steel, zinc and copper) and the results are summarised in Fig. 3. The DRFs employed to compute the losses for different materials are generally those currently available in the published literature (see Table 3). All the materials selected for this case study have their own significance. For 
instance, limestone is often used in heritage buildings whereas carbon steel is widely used in built infrastructure for the construction of residential, commercial and industrial buildings as well as bridge structures. Zinc and copper are widely used as roofing and cladding materials in buildings. These materials are assumed to be exposed in unsheltered environmental conditions in London. For the purposes of the intercomparability analyses, we have adopted the air pollution and climate data from Brimblecombe and Grossi (2008) for the years 1990 and 2010. $\mathrm{PM}_{10}$ data is taken from Fuller and Green (2006) and IAEI (2006). Dry deposition velocities for $\mathrm{SO}_{2}$ and $\mathrm{HNO}_{3}$ are assumed to be 0.38 and $0.32 \mathrm{~cm} \mathrm{~s}^{-1}$, respectively (Sabboni et al., 2006). The subsequent paragraphs discuss the results obtained from this case study and the further Section 3.2.2 provides summary and critical discussion of the results.

The common observation from Fig. 3 is that material losses averaged over the values computed by various DRFs for an individual material have decreased in 2010 from the 1990 levels, mainly due to reduced concentrations of $\mathrm{SO}_{2}, \mathrm{O}_{3}$ and $\mathrm{PM}_{10}$. These were found to be fallen by 3.2, 9.8, 4.3 and $19.2 \%$ in 2010 from the 1990 levels for carbon steel, limestone, zinc and copper, respectively. However, the main objective of these computations is not to demonstrate the long-term temporal trend of material loss, as recently presented by studies elsewhere (Brimblecombe and Grossi, 2008; Graedel and Leygraf, 2001; Grossi et al., 2008; Tidblad, 2012), but to analyse the comparability of results obtained from various DRFs for identical input parameters and compare the estimated values with those published in literature.

Inter-comparison of modelled results using different DRFs show reasonably close values to each other for all materials. The coefficient of variances $(\mathrm{CoV})$ were computed in each case to assess the inter-comparability of different DRF results. For instance, 4 different DRF models were applied to measure the surface recession of limestone (Fig. 3a). These produced the highest CoVs among all materials considered as 0.25 and 0.30 for 1990 and 2010, respectively. This variability is mainly dominated by the Lipfert (1998) function which produces the largest surface recession compared with other 3 functions used, because of its relatively higher weightage for precipitation (i.e. karst effect). As seen in Table 3, the structure of the Lipfert function recognises the three mechanisms for material loss: (i) karst effect $\left(\mathrm{CO}_{2}\right.$ weathering), (ii) acid rain effect, and (ii) dry deposition (Brimblecombe and Grossi, 2008). The current estimates are for "clean precipitation" and ignore the maritime influence on the karst effect, given that deposition of sea salt aerosol has maximum effect within the first $100 \mathrm{~m}$ (Bonazza et al., 2009). The recession estimates are found to be dominated by the karst effect set as 18.8 $\mu \mathrm{m}$ per $\mathrm{m}$ precipitation per year, which contributed to over $90 \%$ of total estimated surface recession (Fig. 3a). However, the work by Bonazza et al. (2009) indicates that the choice of the above value is acceptable because (i) natural recession rate becomes large only when the porosity of material exceeds $\sim 25 \%$, and (ii) most of building stones 
are of medium porosity, thus falling close to the value adopted by Lipfert. Otherwise, the remaining three models for limestone produce results nearly close to each other (i.e. $8.37 \pm 1.06$ and $7.41 \pm 1.16 \mu \mathrm{m} \mathrm{yr}^{-1}$ for 1990 and 2010 , respectively). The main difference between the Lipfert and other functions are that Tidblad et al. (2001) takes temperature into account, Kucera et al. (2007) omits temperature and introduce relative humidity and $\mathrm{PM}_{10}$, and Screpanti and Macro (2009) include temperature, relative humidity and $\mathrm{PM}_{10}$. All these three input variables are not part of the Lipfert function which provides considerable weight to karst effect and underestimates surface recession caused by atmospheric pollutants (Bonazza et al., 2009; Delalieux et al., 2002). The trend of getting the largest recession rates by the Lipfert (1998) function is consistent with the results obtained by Grossi et al. (2008) for Oviedo (Spain), Paris (France) and Prague (Czech Republic) where they applied Lipfert (1998), ICP (Tidblad et al., 2001) and MULTI-ASSESS (Kucera et al., 2007) DRFs. Our annual recession rates compare well to those estimated by Kucera et al. (2007) for London for the years 1997-2001 ( 8 $\mu \mathrm{m}$ $\mathrm{yr}^{-1}$ ) using their function for multi-pollutant situation and are on the upper end of the tolerable levels $\left(8 \mu \mathrm{m} \mathrm{yr}^{-1}\right)$ for limestone (Kucera et al., 2005).

The DRFs developed by the Noah's Ark (2006) and MULTI-ASSESS (Kucera et al., 2007) projects were used for estimating surface recession of carbon steel. These produced remarkably less variability in results for both the years (i.e. $\mathrm{CoV}=0.03$ for 1990 and 0.04 for 2010; see Fig. 3b). Given that salt aerosol deposition generally does not exceed $5 \mathrm{~km}$ from the shore with the maximum deposition within the first $100 \mathrm{~m}$ (Bonazza et al., 2009) and that of the unavailability of sea salt data, we ignored $\mathrm{Cl}^{-}$ deposition terms from both functions. Results indicate $\mathrm{SO}_{2}$ as the most sensitive term, followed by $\mathrm{PM}_{10}$, in these functions dictating the total recession values. Our estimates are on the higher end to those reported by the United Nations report (UN, 2008) as 26 and $28 \mu \mathrm{m} \mathrm{yr}^{-1}$ in London during 1990 and 2010, respectively. This is because our $\mathrm{SO}_{2}$ concentrations (20 and $17 \mu \mathrm{g} \mathrm{m}^{-3}$ ) are up to 2 times larger than the constant concentrations $\left(10 \mu \mathrm{g} \mathrm{m}^{-3}\right)$ assumed by the UN (2008) estimates. The average surface recession was found to be about 1.60 and 1.50 times larger in 1990 and 2010, respectively, than the tolerable values $\left(20 \mu \mathrm{m} \mathrm{yr}^{-1}\right)$ for carbon steel (Kucera et al., 2005). These observations clearly suggest a need to control the emissions of $\mathrm{PM}_{10}$ for reducing the carbon steel recession to tolerable levels.

The ICP (Tidblad et al., 2001) and MULTI-ASSESS (Kucera et al., 2007) DRFs are used for estimating corrosion losses to zinc and copper. As expected, these functions produced consistently comparable estimates for both the materials as evident from close to zero CoV values (Figs. 3c and d). Consistent with previous cases, the material loss for both zinc and copper is higher in 1990 compared with 2010, mainly because of reduced $\mathrm{SO}_{2}$ and $\mathrm{O}_{3}$ concentrations. Our estimates for zinc $\left(9.29\right.$ and $8.90 \mathrm{~g} \mathrm{~m}^{-2}$ for 1990 and 2010, respectively) and copper (9.54 and $8.00 \mathrm{~g} \mathrm{~m}^{-2}$ for 1990 and 2010, 
respectively) were found to be comparable to those reported by Kucera et al. (2007) and Kucera et al. (2005) during 1997-2001 (i.e. $\sim 8 \mathrm{~g} \mathrm{~m}^{-2}$ ) and 2002 (i.e. up to $\sim 7 \mathrm{~g} \mathrm{~m}^{-2}$ ) for London, respectively.

\subsubsection{Discussion: practical application and limitations of the DRFs}

DRFs should ideally be suitable for mapping any area with increased risk of corrosion and allowing costing of corrosion damage, as applied by recent studies (Karaca, 2012; Tidblad, 2012). There are a number of functions available in the literature based on linear or non-linear empirical equations (Table 3) but they should be generalised cautiously for untested conditions. This is because their outputs may differ depending on the assumptions, mainly driven by precipitation, concentrations of pollutants and relative humidity (Grossi et al., 2008). This can be argued that which function should be selected when more than one DRF is available for a particular material? The key in such a case is to carefully assess the climate and pollution conditions in which the DRFs are developed. For instance, the DRFs developed before or in early 2000 (e.g. through the ICP; Tidblad et al., 2001) could work well for $\mathrm{SO}_{2}$ dominating environments such as in Asian cities (see Section 2.6). Recently developed functions (e.g. through MULTI-ASSES project; Kucera et al., 2007) would be more appropriate for the multi-pollutant environmental conditions, generally dominated by the road vehicle emissions. When available DRFs were used on selected materials in Section 3.2.1, all the functions provided reasonably close values (Fig. 3). However, one limitation of this case study is that only modelled results are compared with each other and these are not evaluated against the measured values for real structures. Furthermore, most of the available functions are developed by exposing the specimens in sheltered/unsheltered conditions, but not the real structure. Previous research has shown that the orientation of the exposed specimen can affect the amount of deterioration considerably (Knotkova et al., 1982; Coburn et al., 1995). Further concern could include the reliability of long-term future projections using the available DRFs under the changing environmental conditions for real structures, especially at the locations other than where they were originally developed. There appears to be a clear need for developing more robust and theoretical functions, and their performance evaluation against the measured data, which could be adopted for a variety of environmental and pollution conditions (Grossi et al., 2008).

\section{Changing environmental conditions: structural and economic impacts on the integrity of built infrastructure}

In addition to the chemical pathways described in the previous sections, changing and extreme environmental conditions arising from climate change may also have the potential to affect the structural integrity of the building and transport assets. Table 5 summarises such potential impacts due to the following projected global climatic conditions: (i) warmer and wetter winters; an average global rise in temperature that can 
range from 1.4 to $5.8{ }^{\circ} \mathrm{C}$ between 1990 and 2100 (Climate Change, 2007; IPCC, 2007), (ii) increase in extreme rainfall amounts and more frequent extreme precipitation events (IPCC, 2007; TRB, 2008), (iii) hotter and drier summers with more frequent and extreme high temperatures (Arkell and Darch, 2006; IPCC, 2007), and (iv) rise in global sea level ranging from 18 to $59 \mathrm{~cm}$ between 1990 and 2100 with an increased risk of tidal surges (relative mean sea level rise) (IPCC, 2007).

The recent UK Climate Change Risk Assessment report has identified the most significant risks due to changing environmental conditions on a wide range of sectors ranging from agriculture and forestry, business, health and wellbeing to buildings and infrastructure and the natural environment (CCRA, 2012). Risks have been prioritised according to their criticality and potential impact. The main structural risks that have been identified for buildings are damage to properties due to flooding and coastal erosion as well as subsistence (settlements). On the other hand, the main risks for transport infrastructure have been identified as flooding of roads and railways, scouring of road and rail bridges, and landslips.

Significant economic impacts are estimated due to these climate changes. For example, the total value of assets of 136 port cities worldwide, which have a population over 1 million, exposed to sea level rise is estimated to be more than $\$ 3,000$ billion (Nicholls et al., 2007). A past study by Larsen et al. (2008) estimated about $\$ 3.6-\$ 6.1$ billion future costs to the Alaska public infrastructure from today until 2030 and 5.6-\$7.6 billion from today until 2080. The Stern reports prepared by the British government projected that climate change could cost the world's economy nearly $5 \%$ of global gross domestic product, if nations do not take action to mitigate the effect of GHGs and adapt to projected changes in precipitation and temperature (Stern, 2007; Stern et al., 2006). Another study for London transport raised similar concerns (Arkell and Darch, 2006). They reported that climate change will worsen the already existing risk on London transport infrastructure if forward planning and cost-effective mitigation measures are not adopted. Furthermore, in London alone, there are currently more than half a million properties at risk from flooding with an estimated asset value of $£ 80$ billion (Lavery and Donovan, 2005). Direct damage in the event of a future tidal flood is estimated to be in excess of $£ 30$ billion.

The increased frequency and intensity of extreme weather events, such as heat waves or intense rainfalls, in the future has the potential to cause significant structural damage to buildings and the transport infrastructure assets. Such effects are likely to take place within a short period of time (hours/days) and an example would be the potential of river flooding arising from extreme rainfall resulting in loss of stability of bridge foundations due to scour. Impacts from short-lived extreme weather events are likely to be accompanied by changes in the long-term (years/decades) deterioration of structural 
materials, buildings and the elements of the transport infrastructure. These long-term effects are derived by the changes in average climatic conditions and would affect life expectancy and maintenance costs of structures. Consequently, a structure which has already seen some deterioration arising from chemical pathways (as described in Section 3) will be weaker in the event of extreme weather affecting it.

The following section provides an example case study for demonstrating the effects of changes in average environmental conditions on the long-term deterioration rate of a widely used structural material, carbon steel. This is followed by a qualitative overview of potential damages and failures expected in the built infrastructure during extreme environmental conditions and weather events.

\subsection{Case study: effect of changes in average environmental conditions on deterioration of carbon steel}

A widely used material, carbon steel, is considered here to investigate the effect of changing environmental conditions on thickness loss over the period between 2010 and 2090 for four different scenarios (Fig. 4). The chosen scenarios represent varying climate conditions. The DRF proposed by Kucera et al. (2007) is used to estimate the total material mass loss which is then converted into thickness loss by dividing the former by the density of carbon steel (assumed as $7.86 \mathrm{~g} \mathrm{~cm}^{-3}$ ). The key inputs to the DRF include climate parameters and the ambient concentrations of $\mathrm{SO}_{2}, \mathrm{PM}_{10}$ and $\mathrm{H}^{+}$. This particular DRF was chosen because of its capability to capture gradual changes in climate parameters over time. The values for climate parameters are obtained from the UK Climate Projections database (UKCP09, 2009) for the area of west London for the medium emissions scenario (see Table 6). The $\mathrm{SO}_{2}$ and $\mathrm{PM}_{10}$ concentrations are taken from Brimblecombe and Grossi (2008). $\mathrm{H}^{+}$concentrations are not considered for the purposes of this case study since only the trends, and not the actual absolute values, are of interest. Scenario 1 (base case) assumes that both the climate parameters and pollutants concentrations vary over time according to the trends shown in Table 6 . Scenario 2 (no climate parameters and pollutants change) assumes that the climate parameters and the $\mathrm{SO}_{2}$ and $\mathrm{PM}_{10}$ concentrations remain constant, at their 2010 values, over time. Scenario 3 (no pollutants change) assumes that the climate parameters vary as shown in Table 6 but the $\mathrm{SO}_{2}$ and $\mathrm{PM}_{10}$ concentrations remain at their 2010 values over time; this effectively aims to capture solely the effects of changing environmental conditions. Lastly, Scenario 4 (precipitation increase) is similar to the Scenario 1 (base case) but assumes a 20\% gradual increase in precipitation up to 2090.

A general observation from Fig. 4 is that any potential impacts of changing environmental conditions on the amount of material loss start becoming evident after the second half of this century. Comparison of the "base case" with Scenario 2 shows that the effect of a potential reduction in pollutants concentrations will be a reduction in 
the thickness loss experienced by carbon steel. This effect, however, is relatively small. For instance, a 30\% decrease in the $\mathrm{SO}_{2}$ concentration results in only a 3\% reduction in total thickness loss by the 2090s. The effects of temperature and relative humidity can be observed by comparing Scenario 3 with Scenario 2 where in the latter it is assumed that temperature and humidity remain at their 2010 values. Scenario 3 can be seen to result in 3\% lower thickness loss which demonstrates that the projected increase in average temperature and reduction in average humidity is expected to have a slightly positive effect on the deterioration rate of carbon steel. The effect of precipitation can be seen from Scenario 4 which shows that a $20 \%$ potential increase in average annual precipitation by 2090 over the 2010 levels will result in an $18 \%$ increase in total thickness loss.

It should be noted that the above observations have been obtained for a specific location in the UK (west London) and for specific $\mathrm{SO}_{2}$ and $\mathrm{PM}_{10}$ concentrations. It would be unwise to generalise the results since these are likely to be site-specific depending on the climatic parameters and pollutant concentrations. Nevertheless, the results in Fig. 4 have demonstrated that changing average environmental conditions may have a slightly positive effect on the future deterioration rate of carbon steel. Thickness loss was found to be more susceptible to changes in average precipitation amounts rather than temperature and relative humidity values. These results agree with the findings of detailed investigations carried out by Kallias and Imam (2012) on the reliability of carbon steel bridge structures.

\subsection{Buildings}

Worldwide floods are currently the second costliest weather-related catastrophe after windstorms which are likely to increase due to rising sea levels and tidal surges (ABI, 2005). The damage caused by flooding normally affects buildings and their contents at basement and ground level depending on the level of water reaching to them. The risk is present for both global flooding brought by increased river flows and local flooding due to insufficient drainage capacity under more intense rainstorms. Hall et al. (2006) reported that the expected annual damage in England and Wales due to coastal flooding is predicted to increase from the current $£ 0.5$ billion to $£ 1-£ 13.5$ billion by 2080 , depending on the scenarios of climate and socio-economical change. Their earlier study also showed that the frequency of flooding is projected to increase more on the coasts than on rivers (Hall et al., 2005). An indication of the overall vulnerability from flood risks in the UK is indicated by a large number (about 5 million) of people living in approximately 1.8 million houses in UK flood plains (Stansfield, 2001). This has led to the preparation of strategic coastal management plans, such as retreat of the vulnerable population, as an attempt to reduce the overall risk (Vega-Leinert de la and Nicholls, 2008). Likewise, studies investigating the impacts of climate change in the United 
States report that the impact of river flooding on the Boston metropolitan area has doubled the overall cost of flood damage (Kirshen et al., 2004; Suarez et al., 2005).

The potential occurrence of higher intensity as well as more frequent gales and winds is likely to increase the repair costs and the risk of roof failures, chimneys and external cladding in buildings (Sanders and Phillipson, 2003). Roof structures and the buildings underneath are also expected to be affected by extreme precipitation events resulting, in many cases, from inadequate drainage. There is also a risk that hotter and drier summers and increased exposure to UV radiation due to reduction in cloud amount could lead to possible increase in degradation of roof membranes and exterior finishes resulting in damage (Nijland et al., 2009; UKCIP, 2003).

Subsidence of buildings and performance of foundations due to drying out of clay soils is expected to worsen (Ross et al., 2007; Sanders and Phillipson, 2003). The expected higher temperatures and drier weather during summer will result in a decrease in soil moisture content and therefore lead to shrinkage and subsequent potential ground movements and settlements. These movements may affect the global stability of buildings and may result in structural damage, especially in the cases of shallow foundations, but it may also give rise to non-structural damage such as cracking to walls and finishes. For example, the heat wave observed in the UK in 2003 resulted in insurance claims for building subsidence damage over $£ 300$ million, which was nearly twice the value of the 1995 heat wave (Hunt et al., 2006). It is estimated that this may further increase by 50 to $100 \%$ in the future due to the changing environmental conditions (Stansfield, 2001). The effects of vegetation and trees around buildings can also become detrimental and cause the ground to shrink and subside because they extract water from the soil (Page, 1998). This can be exacerbated with the effect of warmer summers where trees will tend to extract more water resulting in higher subsidence.

The increase in temperature extremes is also expected to affect the thermal expansion and contraction of materials leading to more intense thermal cycle movements which can result in cracking problems associated with buildings, cladding, sealants and roofing membranes (Graves and Phillipson, 2000; Holper et al., 2007; UKCIP, 2003). Increases in very hot days and heat waves will also pose limits on periods of construction activity due to health and safety concerns.

Changes in the intensity of driving rain (intense rainfall combined with strong winds) in the future may cause problems to current designs of external cladding and cavity walls and the interface of windows and doors with walls (UKCIP, 2003). Contrary to what might be expected considering the increase in global average temperature, freeze-thaw damage may not decrease. It has a potential to increase because materials may be wetter 
at the onset of frost, due to the expected higher precipitation amounts leading to more frost damage (Nijland et al., 2009).

\subsection{Transport infrastructure}

Transport infrastructure systems, which are designed to be operational over a long time period, are increasingly likely to experience the impact of climate change over their lifetime. Reliable estimates of future climatic conditions are essential in order to aid infrastructure owners manage the impact of climate change on both existing and planned infrastructure. Climate change impact planning for new items of infrastructure will ensure continuous functionality throughout their life. Assessment of the existing infrastructure by considering climate change effects will help infrastructure managers to plan maintenance, modification or, in extreme cases, replacement schemes.

Due to the inherent uncertainty associated with climate change predictions and assessment of future economic costs, the challenge is to attempt quantifying the effects of climate change. The impacts can be direct, which is related to effects on built assets such as bridges, highways, railway lines, ports, airport, earthworks, or indirect, which can be related, for example, to the reduction or loss of functionality of the transportation network, costs associated with climate change adaptations, environmental and societal economic losses.

\subsubsection{Roads}

The deterioration of road surface materials such as asphalt and concrete pavements is expected to increase due to the effects of prolonged high temperatures resulting in softening, material breakdown, cracking and loss of road surface integrity (DoT, 2005; Holper et al., 2007; Hudson, 2004; Karl et al., 2009; TRB, 2008; Walters, 2009; Willway et al., 2008). A recent study by Anyala et al. (2011) reports that the cumulative rut depth expected in road pavements may increase as much as three times by the 2050s from the present day due to the effects of increased temperature owing to climate change. The higher risk of flooding in the future will increase the cases of subsidence and flood damage to roads. For example, the extreme summer temperatures observed in the UK in 2003 resulted in severe road subsidence problems reaching a total cost of nearly $£ 40$ million (Hunt et al., 2006). A case study by Hudson (2004) has shown that annual road maintenance costs in the UK may increase up to 60 times by the 2080s due to climate change. A similar study in Australia has shown that agency costs for pavement maintenance and rehabilitation may increase on average by $30 \%$ in the future due to the effects of climate change (Austroads, 2004). Coastal highways will be at increased risk from potential sea level rises and coastal flooding (Karl et al., 2009; Koetse and Rietveld, 2009; Mills and Audrey, 2002). Flooding of road structures may cause significant delays to the transport network due to their unavailability. For example, Kirshen et al. (2004) estimated an $80 \%$ increase in traveller delays due to 
increased incidence of flooding (both river and coastal) in the Boston area resulting in large economic losses. The length of roads in the UK that have significant possibility of river or tidal flooding can increase by $40 \%$ over the present value by the 2080s (CCRA, 2012). Drainage capacity requirements to highways will increase due to increased and more frequent extreme precipitation events, storms and weathering of drains from heat and additional vegetation (DoT, 2005; Holper et al., 2007; West and Gawith, 2005). More intense rainfall will also increase subsidence and heave problems on highways (Walters, 2009). Moreover, the effects of increased tree and plant growth due to future differences in seasonal climate variations may have major consequences for road networks (DoT, 2005; UKCIP, 2003). Traffic signs, gantries and lightning columns are at risk from increased wind speeds and more frequent storms (Karl et al., 2009). The latter can also result in more debris being carried out on roads, interrupting travel.

\subsubsection{Railways}

The increase in the frequency of occurrence of extreme summer temperatures is expected to cause deformation of rail tracks and increase the risk of rail buckling, leading to speed restrictions and causing disruption to the transport system (Baker et al., 2010; Dobney et al., 2009; Holper et al., 2007; Karl et al., 2009; Mills and Audrey, 2002; RSSB, 2003; TRB, 2008). For example, the heat wave observed in the UK in 2003 has resulted in a large amount of buckled rails and significant delays to the rail network which resulted in a total cost exceeding £3.5 million (Arkell and Darch, 2006; Hunt et al., 2006). A recent risk assessment has shown that the number of rail track buckles in the UK may increase up to four times by the 2080s, from its present value, due to the expected increase in hot weather during summers (CCRA, 2012). The associated cost with the rail buckles and delays caused is set to increase by 30 to $50 \%$ by the 2080s (Dobney et al., 2010). The risk of disruptions to railway lines due to flooding, wind damage, and landslips is also expected to increase. A case study for Scotland, for instance, has shown that the cost impacts of climate change may increase by as much as $40 \%$ for the rail network in the future (Metroeconomica, 2004). The length of railway line at significant risk of flooding in the UK may increase by as much as $35 \%$ over its present value by the 2080s (CCRA, 2012). Furthermore, sections of the railway network that are built along coasts will be more vulnerable to coastal flooding and storms and to sea level rises (Baker et al., 2010; Karl et al., 2009; RSSB, 2003; West and Gawith, 2005). Increases in vegetation growth and changes in leaf fall patterns may cause more slipperiness in rails and may have the potential of adversely affecting railway lines and the operation of rail networks (DoT, 2005; RSSB, 2003; UKCIP, 2003).

\subsubsection{Bridges}

Consideration of environmental conditions for the design and maintenance of bridge structures is vital for the safety of bridge infrastructure. Bridges are most 
vulnerable to natural hazards such as flooding, storms, hurricanes and winds. Statistics on bridge collapses worldwide reveal that natural hazards are the predominant cause of failure (Imhof, 2004). This demonstrates, bearing in mind the adverse climate change impacts, the high risk present in the future for bridge structures and transport networks with respect to weather-related extreme events.

One of the key effects of climate change on the bridge population will be the increased risk of scour of bridge piers and abutments (DoT, 2005; RSSB, 2003; TRB, 2008). This will arise from more frequent and more intense river flooding due to the expected increases in precipitation in the future. Scour is caused by the erosive action of flowing water, removing sediment from around bridge foundations. This has been one of the most common causes of bridge collapses in the past as per the failure statistics reported by Wardhana and Hadipriono (2003), Imhof (2004), JBA Consulting (2004), and Imam and Chryssanthopoulos (2012). Bridge collapses in the previous years attributed to scour and erosion are evidence of the increased risk (Fleming, 2009; Sweeney, 2009). A recent risk assessment has shown that bridge scour may increase by between 5 and $50 \%$ over the present value by the 2080s in the UK, depending on the local bridge site conditions (CCRA, 2012).

From the materials point of view, bridge material durability is also expected to be affected by climate change. Increasing temperatures and rainfall is expected to increase the corrosion of steel in some areas (Holper et al., 2007), increase the carbonisation and corrosion of concrete (DoT, 2005; Peng and Stewart, 2008; Yoon et al., 2007) and accelerate their deterioration process (UKCIP, 2003). Higher summer temperatures will need to be handled by bridge structures and this may affect the movements required at bearings and expansion joints due to higher levels of thermal expansion affecting bridge operations and adding to maintenance costs (Holper et al., 2007; Karl et al., 2009; Meyer, 2006; TRB, 2008).

Increase in wind speeds and the occurrence of storms will pose further risk to bridge structures in terms of the stability of their decks (DoT, 2005; Karl et al., 2009). Drainage systems for bridges may be overloaded and may need to be changed as a result of increased precipitation and weathering from heat (DoT, 2005; Karl et al., 2009; RSSB, 2003; Walters, 2009). Wetter winters coupled with drier summers are also expected to have an adverse effect on soil moisture content which can lead to foundation settlement and landslip problems (DoT, 2005; RSSB, 2003; TRB, 2008). Potential sea level rises may affect coastal bridges, especially if they have low clearances below the deck with storm surges and wave actions affecting the stability of the decks (Meyer, 2006).

\subsubsection{Seaports}


To date, very little work has been carried out to assess the impacts of climate change on seaports. The principal impact of climate change on ports will be in the higher tidal levels caused by sea level rise and changes in surge and wave conditions (ICF International, 2006; Karl et al., 2009; West and Gawith, 2005). These would lead to increased risk of overtopping and damage to existing flood defences. Sea level rise will also reduce the clearance under bridges in ports having an adverse impact on the passages of ships underneath them (Gill et al., 2009). Potential increase in wind speeds in the future can affect operations of the cranes at ports increasing the risk of accidents. Furthermore, it was shown that climate change will result in an increase in sea water temperature and salinity in large areas of the Atlantic and Indian Oceans (Bindoff et al., 2007). This may lead to increased corrosion and deterioration of port structures since this is directly affected by the concentration of chlorides in sea water (PIANC, 2008). At a minimum, all the above impacts are likely to result in increased weather-related delays and periodic interruption of shipping services.

\subsubsection{Airports}

Flooding of airport runways due to extreme rainfalls and sea level rises can be considered as one of the most important risks faced by airports due to climate change (Karl et al., 2009; Pejovic et al., 2009). The capacity of storm water collection and drainage systems may need to be increased to accommodate the expected future increases in rainfall. On the other hand, rising temperatures will affect the deterioration of runway pavements in much the same way they affect highways, resulting in heat buckling problems (Karl et al., 2009). Coastal airports will become more vulnerable from coastal flooding and the increase in sea level rises (Peterson et al., 2006).

\subsubsection{Earthworks and embankments}

Earthworks make up a large proportion of transport networks. In the UK, there are about 20,000 $\mathrm{km}$ of embankments and cuttings (Loveridge et al., 2010). In fact, about one fourth (£20 billion) of the total asset value of major highway infrastructure in the UK is earthworks (Walsh et al., 2007). The long-term performance and stability of earthworks and slopes is significantly influenced by both precipitation and temperature conditions by affecting the seasonal pore pressure distribution within them. In a changing climate, it is possible that failure mechanisms for these structures will alter as a result of changes in the moisture content of the soil material of the slopes. Therefore, the risk of failure at sites where these earthwork structures are located across the transport network will change. The increase in heavy rain events due to climate change can be expected to have a significant effect on embankments and slopes where landslides can take place (Karl et al., 2009; Mills and Audrey, 2002; RSSB, 2003; Walters, 2009; West and Gawith, 2005). Clay slopes in particular will be at greater risk in the future from increased magnitude seasonal cycles of moisture change leading to strength degradation (Loveridge et al., 2010). As an example, the winter of 2000/1 was 
the wettest on record in many parts of the UK and rainfall caused more than 100 slope failures in southern UK alone and additional damage in Scotland (Messafer, 2008). The incidence of landslides is projected to increase with double the number of roads in the UK being at risk by the 2080s compared with present values (CCRA, 2012). Drier summers will also exacerbate subsidence in earthworks which is caused by the drying and shrinking of soil making it unstable (Baker et al., 2010; Daeid and Thain, 2002; West and Gawith, 2005).

\subsubsection{Tunnels}

The expected increase in precipitation levels will have an adverse effect on soil moisture levels which may put additional risk to the structural integrity of tunnels (RSSB, 2003). Clay shrinkage is one particular threat to tunnel structures resulting in subsidence and heave problems. Underground tunnels will be susceptible to more frequent flooding having an adverse effect for the operation of metro systems (Karl et al., 2009; TRB, 2008). For example, it is stated that the projected sea level increase in the New York area by the 2080s poses the risk of covering a large number of metro tunnel entrances (TRB, 2008). On the other hand, changes in levels of the water table could also impact groundwater tunnels due to increased water pressure on their walls. Such groundwater pressures increases acting on the tunnel walls can cause tunnels to float or crack resulting in tunnel flooding.

\subsubsection{Coastal defences}

In many cases, coastal defences can be regarded as part of the transport infrastructure since they act to protect highway and railway networks. Security breach of coastal defences is likely to occur more frequently due to sea level rises, more intense storm, flooding, wave loading and erosion (Hall et al., 2006; West and Gawith, 2005). For instance, a case study carried out in the UK showed that the expected sea level rise and larger wave heights can increase the annual probability of failure of sea walls by a factor of 100 (Hawkes et al., 2003). A similar study has shown that if present-day coastal defences in the UK remain unchanged, overtopping rates can increase as much as $80 \%$ compared to the present rates (Sutherland and Gouldby, 2003).

\section{Summary, conclusions and future research challenges}

This article discussed the footprints of air pollutants and changing environment on the sustainability of built infrastructure. The air pollutants such as $\mathrm{SO}_{2}, \mathrm{O}_{3}$ and $\mathrm{NO}_{\mathrm{x}}$ are corrosive gases that deteriorate building materials through chemical routes (see Tables 2 and 3). Whereas the alterations in $\mathrm{CO}_{2}$ concentrations play a key role in changing climate parameters through climate change effects besides directly affecting the concrete structures through a carbonation process. The acidic nature of corrosive air pollutants and their ambient concentrations are equally important for geologically sensitive industrial areas where a peculiar combination of corrosive air pollutants and 
climate parameters (e.g. high relative humidity) can deteriorate structures of high importance (e.g. museums) from both the inside and outside. Tropospheric $\mathrm{O}_{3}$ is the powerful oxidiser and is currently of most concern because of its global background concentrations being over the tolerance limits of materials, and not being any positive signs of decrease in near future (Jacob and Winner, 2009). Conversely, impact of $\mathrm{SO}_{2}$ on various building materials is expected to fall considering the forecasted decrease in its concentration, particularly in developed countries like the USA, Germany and UK (Ramanathan and Feng, 2009). In line with the projected trend of Grossi et al. (2008), our first case study carried out on four materials (carbon steel, limestone, zinc and copper) suggested a similar decreasing trend for material deterioration in London, along with a reasonable agreement between the recession rates computed using different DRFs with identical input parameters. It is concluded that unlike metals and stone, extremely limited information is available on the impact of chemical pathways on wooden, brick and concrete structures and further detailed studies are essential for quantifying their damage.

Literature suggests that changing environmental conditions are expected to affect the integrity of buildings and transport infrastructure by affecting the durability of materials employed as discussed in Section 3. The results of our second case study revealed that projected changes in temperature and/or relatively humidity will have only a modest effect on the deterioration rate of carbon steel. The effect of changes in precipitation and the $\mathrm{SO}_{2}$ concentration were found to have a more significant impact on thickness loss of carbon steel. For combating the climate change effects on built infrastructure, a progressive control of air pollution from local-to-regional-to-global scales is required. With the development of knowledge data base on various pollutants, risk-effect based approaches for air pollution control have also evolved recently (Longhurst et al., 2009). These generally concern public health and major environmental impacts associated with the climate change. The built infrastructure also perceives advantages of tight air pollution control measures; for example, concentrations of acidic air pollutants are expected to decrease in many parts of the world (Brimblecombe and Grossi, 2007). However, impacts of air pollution on various built infrastructures of historic or public relevance are generally overlooked when appending or designing new air pollutant regulations. One of the major reasons for this includes lack of adequate quantitative information on these aspects. It is therefore important to develop local air quality action plans considering the periodic evaluation of the selected built infrastructures of interest. These inputs could then feed into to regional or global policies. Unfortunately, assessing the impacts of air pollutants and climate change on built infrastructure is a long term process. Therefore, long-term monitoring studies with a periodic evaluation of air pollution and structural deterioration could help mapping the risks of corrosion damage more precisely. 
One of the most critical steps in adapting infrastructures is the integration of adaptation and mitigation considerations into standards and decision-making. This will require cost-benefit analysis, modification of technical standards and criteria to better match estimates of future climatic conditions and protection as well as retrofitting of existing infrastructure assets. Construction techniques and materials employed will require adjustments to better reflect the demands of potentially more variable and extreme climatic conditions. The whole process will require the identification and prioritisation of critical infrastructure assets which require immediate attention and reinforcement (RAEng, 2011). Although generic risk-based frameworks for assessing different adaptation options have been developed during the past years, there is very little information available on how adaptation costs compare to the potential damages of not adapting and how the adaptation costs would change if there were more mitigation actions (EEA, 2007). More work is clearly needed in this challenging area.

A lot more focused research studies are needed for the accurate quantification of the deterioration of steel, concrete, brick and wood structures in the UK and other regions. The outputs of these studies would help the local governments to design future adaptation and mitigation plans for controlling air pollution and protecting the corrosion of the existing built infrastructure. A holistic approach, which interlinks material deterioration with the air pollutants and changing environmental conditions, would be of great value for assessing the safety performance, reliability and robustness of infrastructural assets. There is also a need for developing more generic, robust, and theoretical DRFs that can be used for mapping corrosion damage in an area, costing associated risk due to this damage, and designing relevant mitigation strategies. The corrosion data from a greater number of field studies conducted on various types of building materials exposed in the range of varying environmental conditions and at different geographical locations could help the performance evaluation of the theoretical DRFs.

\section{Acknowledgements}

Authors thank the anonymous reviewers for their valuable comments and time to review the manuscript.

\section{References}

ABI, 2005. Association of British Insurers. Financial risks of climate change. Climate Risk Management, Metroeconomica, UK.

Anyala, M., Odoki, J.B., Baker, C., 2011. Assessment of the impact of climate change on road maintenance. Proceedings of the $2^{\text {nd }}$ International Conference on Advances in Engineering and Technology (AET2011), Uganda.

Arkell, B.P., Darch, G.J.C., 2006. Impact of climate change on London's transport network. Proceedings of the Institution of Civil Engineers: Municipal Engineer 159(ME4), 231-237. 
Aaheim, A. H., Kristin, A., Seip, H.M., 1999. Climate Change and Local Pollution Effects - An Integrated Approach. Mitigation and Adaptation Strategies for Global Change 4, 61-81.

Athanassiadou, M., Baker, J., Carruthers, D., Collins, W., Girnary, S., Hassell, D., Hort, M., Johnson, C., Johnson, K., Jones, R., Thomson, D., Trought, N., Witham, C., 2010. An assessment of the impact of climate change on air quality at two UK sites. Atmospheric Environment 44, 1877-1886.

Austroads, 2004. Impact of climate change on road infrastructure. Austroads Project No. RSM.S.N.503, Publication No. AP-R243/04, Sydney.

Baker, C.J., Chapman, L., Quinn, A., Dobney, K., 2010. Climate change and the railway industry: a review. Proceedings of the Institution of Mechanical Engineers 223, Part C: Journal of Mechanical Engineering Science 224, 519-527.

Bastidas-Arteaga, E., Chateauneuf, A., Sanchez-Silva, M., Bressolette, P., Schoefs, F., 2010. Influence of weather and global warming in chloride ingress into concrete: A stochastic approach. Structural Safety 32, 238-249.

Bindoff, N.L., Willebrand, J., Artale, V., Cazenave, A., Gregory, J., Gulev, S., Hanawa, K., Le Quéré, C., Levitus, S., Nojiri, Y., Shum, C.K., Talley, L.D., Unnikrishnan, A., 2007. Observations: Oceanic Climate Change and Sea Level. In: Climate Change 2007: The Physical Science Basis. Contribution of Working Group I to the Fourth Assessment Report of the Intergovernmental Panel on Climate Change [Solomon, S., Qin, D., Manning, M., Chen, Z., Marquis, M., Averyt, K.B., Tignor, M., Miller, H.L. (eds.)]. Cambridge University Press, Cambridge, United Kingdom and New York, NY, USA.

Bonazza, A., Messinaa, P., Sabbionia, C., Grossi, C.M., Brimblecombe, P., 2009. Mapping the impact of climate change on surface recession of carbonate buildings in Europe. Science of the Total Environment 407, 2039-2050.

Booij, M.J., 2005. Impact of climate change on river flooding assessed with different spatial model resolutions. Journal of Hydrology 303, 176-198.

Brimblecombe, P., Grossi, C., 2008. Millennium-long recession of limestone facades in London. Environmental Geology 56, 463-471.

Brimblecombe, P., Grossi, C.M., 2007. Damage to Buildings from Future Climate and Pollution. APT Bulletin 38, 13-18.

Brischke, C., Rapp, A.O., 2008. Dose-response relationships between wood moisture content, wood temperature and fungal decay determined for 23 European field test sites. Wood Science and Technology 42, 507-518.

BS EN ISO 9223., 2012. Corrosion of metals and alloys - Corrosivity of atmospheres Classification, determination and estimation.

BS EN ISO 9224., 2012. Corrosion of metals and alloys - Corrosivity of atmospheres - Guiding values for the corrosivity categories.

CC Report, 2003. Effects of ozone materials: Update in support of the Canadian-wide standards for particulate matter and ozone. Prepared for the Candian Council of Ministers of the Environment, pp. 26, http://www.ccme.ca/assets/pdf/scrvw_oz_effects_materials_e.pdf.

CCRA, 2012. Climate Change Risk Assessment (CCRA) Evidence Report. UK 2012 Climate Change Risk Assessment, Defra, London.

CEB, 1997. New approach to durability design - an example for carbonation induced corrosion. In: Schiessl, P. (ed.), Bulletin, 238, Comite Euro-International du Beton, Lausanne.

Charola, A.E., Lazzarini, L.S., 1986. Deterioration of brick masonary caused by acid rain. ACS Symposium Series, $250-258$

Chin, J.W., Nguyen, T., Aouadi, K., 1997. Effects of environmental exposure on fiberreinforced plastic (FRP) materials used in construction. Journal of Composites Technology \& Research 19, 205-213.

Climate Change, 2007. Climate Change 2007: Synthesis Report, 4th Assessment of the Intergovernmental Panel on Climate Change. pp. 52. http://www.ipcc.ch/pdf/assessmentreport/ar4/syr/ar4_syr.pdf 
Coburn, S.K., Komp, M.E., Lore, S.G., 1995. Atmospheric corrosion rates of weathering steel test sites in the Eastern United States - Affect of environment and test panel orientation. Atmospheric Corrosion. ASTM 1239, Kirk, W.W. and Lawson, H.H. Eds., ASTM International, USA, 101-113.

Coley, D., Kershaw, T., 2010. Changes in internal temperatures within the built environment as a response to a changing climate. Building and Environment 45, 89-93.

Corvo, F., Reyes, J., Valdes, C., Villaseñor, F., Cuesta, O., Aguilar, D., Quintana, P., 2010. Influence of Air Pollution and Humidity on Limestone Materials Degradation in Historical Buildings Located in Cities Under Tropical Coastal Climates. Water, Air \& Soil Pollution 205, 359-375.

Daeid, N.N., Thain, E., 2002. Measurements of temperature rise over time for commercially available night lights (tea lights). Fire Safety Journal 37, 329-336.

Delalieux, F., Cardell-Fernandez, C., Torfs, K., Vleugels, G., Van Grieken, R., 2002. Damage functions and mechanism equations derived from limestone weathering in field exposure. Water Air and Soil Pollution 139, 75-94.

Dobney, K., Baker, C.J., Quinn, A.D., Chapman, L., 2009. Quantifying the effects of high summer temperature due to climate change on buckling and rail related delays in south-east United Kingdom. Meteorological Applications 16.

Dobney, K., Baker, C.J., Chapman, L., Quinn, A.D., 2010. The future cost to the United Kingdom's railway network of heat-related delays and buckles caused by the predicted increase in high summer temperatures owing to climate change. Proceedings of the Instituation of Mechanical Engineers, Part F: Journal of Rail and Rapid Transit 224, 25-34.

DoT, 2005. The Changing Climate: Its Impact on the Department of Transport. Department of Transport, http://www.dft.gov.uk/pgr/scienceresearch/key/thechangingclimateitsim.

Ebi, K.L., Burton, I., 2008. Identifying practical adaptation options: an approach to address climate change-related health risks. Environmental Science \& Policy 11, 359-369.

EEA, 2007. European Environment Agency (EEA). Climate change: the cost of inaction and the cost of adaptation EEA Technical Report No 13, Copenhagen.

Ekström, M., Fowler, H.J., Kilsby, C.G., Jones, P.D., 2005. New estimates of future changes in extreme rainfall across the UK using regional climate model integrations. 2. Future estimates and use in impact studies. Journal of Hydrology 300, 234-251.

Fisher, D.A., Hales, C.H., Wang, W.-C., Ko, M.K.W., Sze, N.D., 1990. Model calculations of the relative effects of CFCs and their replacements on global warming. Nature 344, 513516.

Fleming, D., 2009. Scour revealed as cause of Irish bridge collapse. New Civil Engineer. http://www.nce.co.uk/news/structures/scour-revealed-as-cause-of-irish-bridgecollapse/5207460.article.

Fowler, D., Smith, R., Muller, J., Cape, J.N., Sutton, M., Erisman, J.W., Fagerli, H., 2007. Long-term trends in sulphur and nitrogen deposition in Europe and the cause of nonlinearities. Water, Air, and Soil Pollution 7, 41-47.

Forster, P., Ramaswamy, V., Artaxo, P., Berntsen, T., Betts, R., Fahey, D.W., Haywood, J., Lean, J.e.a., 2007. IPCC Fourth assessment report (AR4) by working group, Chapter 2: Changes in atmospheric constituents and in radiative forcing. pp. 234.

Fuglestvedt, J., Berntsen, T., Myhre, G., Rypdal, K., Bieltvedt Skeie, R., 2008. Climate forcing from the transport sectors. Proceedings of the National Academy of Science 105, 454-458.

Fuglestvedt, J.S., Shine, K.P., Berntsen, T., Cook, J., Lee, D.S., Stenke, A., Skeie, R.B., Velders, G.J.M., Waitz, I.A., 2010. Transport impacts on atmosphere and climate: Metrics. Atmospheric Environment 44, 4648-4677.

Fuller, G.W., Green, D., 2006. Evidence for increasing concentrations of primary $\mathrm{PM}_{10}$ in London. Atmospheric Environment 40, 6134-6145.

Garthwaite, R., Fowler, D., Stevenson, D., Cox, P., Ashmore, M., Grennfelt, P., Amann, M., Anderson, R., Depledge, M., Derwent, D., Hewitt, N., Hov, O., Jenkin, M., Kelly, F., Liss, P., Pilling, M., Pyle, J., Slingo, J., 2009. Ground level ozone in the 21st century: trends, 
interactions with climate and environmental impacts. IOP Conf. Series: Earth and Environmental Science (2009) 6 282002, doi:282010.281088/281755281307/282006/282008/282002.

Gill, S.K., Wright, R., Titus, J.G., Kafalenos, R., Wright, K., 2009. Population, land use, and infrastructure. In: Coastal Sensitivity to Sea-Level Rise: A Focus on the Mid-Atlantic Region. U.S. Environmental Protection Agency, Washington D.C.

Graedel, T.E., Leygraf, C., 2001. Scenarios for atmospheric corrosion in the $21^{\text {st }}$ century. The Electrochemical Society Interface 10, 24-30.

Graves, H.M., Phillipson, M.C., 2000. FB2: Potential implications of climate change in the built environment. British Research Establishment, BRE, Watford, UK.

Grossi, C., Bonazza, A., Brimblecombe, P., Harris, I., Sabbioni, C., 2008. Predicting twentyfirst century recession of architectural limestone in European cities. Environmental Geology 56, 455-461.

Haines, A., Kovats, R.S., Campbell-Lendrum, D., Corvalan, C., 2006. Climate change and human health: Impacts, vulnerability and public health. Public Health 120, 585-596.

Hall, J.W., Sayers, P.B., Dawson, R.J., 2005. National-scale assessment of current and future flood risk in England and Wales. Natural Hazards 36, 147-164.

Hall, J.W., Sayers, P.B., Walkden, M.J.A., Panzeri, M., 2006. Impact of climate change on coastal flood risk in England and Wales: 2030-2100. Philosophical Transactions of the Royal Society A 364, 1027-1049.

Hawkes, P., Surendran, S., D., R., 2003. Use of UKCIP02 climate-change scenarios in flood and coastal defence. Water and Environment Journal 17, 214-219.

Haynie, F.H., 1986. Theoritical model of soiling of surfaces by airborne particles. In: Lee, S.D., Schneider, T., Grant, L.D., Verkerp, P.J. (eds) Aerosols Lewis Publishers, Boca Raton, 951-959.

Helcher, J.J., Boulanger, J., Noel, D., 1991. Microclimates and corrosion of a building. Historic Structures in Contemporary Atmospheres, 20-25.

Herlyn, J.W., Mehlhorn, L., 1999. Deterioration of wood by climatic and air pollution effects. http://de.scientificcommons.org/20325033.

Highways Agency, 2009. Climate change adaptation strategy and framework. http://www.highways.gov.uk/aboutus/documents/CCAF-Strategy_and_Vol_1Rev_B_Nov.pdf.

Hirsch, P., Eckhardt, F.E.W., Palmer Jr., R.J., 1995. Methods for the study of rock-inhabiting microorganisms - A mini review. Journal of Microbiological Methods 23, 143-167.

Hof, T., 1981. Wood deterioration by microorganisms and its prevention. Antonie van Leeuwenhoek 47, 171-173.

Holper, P., Lucy, S., Nolan, M., Senese, C., Hennessy, K., 2007. Infrastructure and climate change risk assessment for Victoria. Report to the Victorian government. Commonwealth Scientific and Industrial Research Organisation, Australia.

Hudson, L., 2004. Highways asset management case study. UKCIP costing method case study, UK Climate Impacts Programme.

Hulme, M., Jenkins, G.J., Lu, X., Turnpenny, J.R., Mitchell, T.D., Jones, R.G., Lowe, J., Murphy, J.M., Hassell, D., Boorman, P., MacDonald, R., Hill, S., 2002. Climate Change Scenarios for the United Kingdom: The UKCIP02 Scientific Report. Tyndall Centre for Climate Change Research, University of East Anglia, Norwich, UK.

Hunt, A., Boyd, R., Taylor, T., Kovats, S., Lachowyz, K., Watkiss, P., Horrocks, L., 2006. Report on the costs of the hot summer of 2003. DEFRA: Climate Change Impacts and Assessment: Cross Regional Research Programme, U.K.

ICE, 2009. Institution of Civil EngineersThe state of the nation: defending critical infrastructure, UK.

ICF International, 2006. Planning for climate change impacts at U.S. ports. White paper, U.S. Environmental Protection Agency. 
Imam B.M., Chryssanthopoulos M.K., 2012. Causes and consequences of metallic bridge failures. Structural Engineering International 22, 93-98.

Imhof, D., 2004. Risk assessment of existing bridge structures. PhD Thesis. University of Cambridge, UK.

IPCC, 2007. Climate change 2007: The Physical Science Basis. Contribution of working group I to the fourth assessment report of the intergovernmental panel on climate change. S. Soloman, D. Qin, M. Manning, Z. Chen, M. Marquis, K.B. Averyt, M. Tignor and H.L. Miller. Cambridge University Press, Cambridge, United Kingdom.

Isaksen, I.S.A., Granier, C., Myhre, G., Berntsen, T.K., Dalsøren, S.B., Gauss, M., Klimont, Z., Benestad, R., Bousquet, P., Collins, W., Cox, T., Eyring, V., Fowler, D., Fuzzi, S., Jöckel, P., Laj, P., Lohmann, U., Maione, M., Monks, P., Prevot, A.S.H., Raes, F., Richter, A., Rognerud, B., Schulz, M., Shindell, D., Stevenson, D.S., Storelvmo, T., Wang, W.C., van Weele, M., Wild, M., Wuebbles, D., 2009. Atmospheric composition change: ClimateChemistry interactions. Atmospheric Environment 43, 5138-5192.

Jacob, D.J., Winner, D.A., 2009. Effect of climate change on air quality. Atmospheric Environment 43, 51-63.

Jacobsen, S., Gran, H.C., Sellevold, E.J., Bakke, J.A., 1995. High strength concrete -Freeze/thaw testing and cracking. Cement and Concrete Research 25, 1775-1780.

Jonson, J.E., Simpson, D., Fagerli, H., Solberg, S., 2005. Can we explain the trends in European ozone levels? Atmospheric Chemistry and Physics Discussion 5, 5957-5985.

JBA Consulting, 2004. Scour and flood risk at railway structures. Final report prepared for Railway Safety \& Standards Board, Project No. T112, Skipton, UK.

Kallias, A.N., Imam, B.M. 2012. Risk assessment of existing bridges under the influence of changing environmental conditions. Proceedings of the First International Conference of Performance-based and Life-cycle Structural Engineering, Hong Kong, China.

Karaca, F., 2012. Mapping the corrosion impact of air pollution on the historical peninsula of Istanbul. Journal of Cultural Heritage, In Press, doi: 10.1016/j.culher.2012.04.011

Karbhari, V.M., Chin, J.W., Hunston, D., Benmokrane, B., Juska, T., Morgan, R., Lesko, J.J., Sorathia, U., Reynaud, D., 2003. Durability gap analysis for fibre-reinforced polymer composites in civil infrastructure. Journal of Composites for Construction 7, 238-247.

Karl, T.R., Melillo, J.M., Peterson, T.C., (eds.). 2009. Global climate change impacts in the United States. Cambridge University Press ISBN: 978-0-521-14407-0.

Kersner, Z., Teply, B., Novk, D., 1996. Uncertainty in service life prediction based on carbonation of concrete. Proceeding of the $7^{\text {th }}$ International Conference on Durability of Building Materials and Components, C. Sjostrom(ed.), E\&FN Spon, London, 13-30.

Kirshen, P.H., Ruth, M., Anderson, W., Lakshmanan, T.R., 2004. Infrastructure systems, services and climate change: integrated impacts and response strategies for the Boston metropolitan area. U.S. Environmental Protection Agency, Washington D.C.

Klinesmith, D.E., McCuen, R.H., Albrecht, P., 2007. Effect of environmental conditions on corrosion rates, Journal of Materials in Civil Engineering, 19, 121-29.

Knotkova, D., Vickova, J., Honzak, J. 1982. Atmospheric corrosion of weathering steels. Atmospheric Corrosion of Metals, ASTM STP 767, Dean, S.W. and Rhea, E.C. Eds. 7-44.

Koetse, M.J., Rietveld, P., 2009. The impact of climate change and weather on transport: An overview of empirical findings. Transportation Research Part D: Transport and Environment 14, 205-221.

Kucera, V., Fitz, S., 1995. Direct and indirect air pollution effects on materials including cultural monuments. Water, Air, \& Soil Pollution 85, 153-165.

Kucera, V., Tidblad, J., Kreislova, K., Knotkova, D., Faller, M., Reiss, D., Snethlage, R., Yates, T., Henriksen, J., Schreiner, M., Melcher, M., Ferm, M., Lefèvre, R.-A., Kobus, J., 2007. UN/ECE ICP Materials Dose-response Functions for the Multi-pollutant Situation. Water, Air, \& Soil Pollution: Focus 7, 249-258.

Kucera, V., Tidblad, J., Samie, F., Schreiner, M., Melcher, M., Kreislova, K., Knotkova, D., Lefèvre, R-A., Ionescu, A., Snethlage, R., Varotsos, R., De Santis, F., Mezinskis, G., 
Sidraba, I., Henriksen, J., Kobus, J., Ferm, M., Faller, M., Reiss, D., Yates, T., Watt, J., Hamilton, R., O'Hanlon, S., 2005. MULTI-ASSESS: Model for multi-pollutant impact and assessment of threshold levels for cultural heritage, pp. 52. Download from: http://www.corr-institute.se/MULTI-ASSESS/.

Kumar, P., Robins, A., ApSimon, H., 2010. Nanoparticle emissions from biofuelled vehicles their characteristics and impact on the number-based regulation of atmospheric particles. Atmospheric Science Letters 11, 327-331.

Kumar, P., Ketzel, M., Vardoulakis, S., Pirjola, L., Britter, R., 2011. Dynamics and dispersion modelling of nanoparticles from road traffic in the urban atmospheric environment - a review. Journal of Aerosol Science 42, 580-603.

Kuribayashi, M., Ohara, T., Morino, Y., Uno, I., Kurokawa, J.-i., Hara, H., 2012. Long-term trends of sulfur deposition in East Asia during 1981-2005. Atmospheric Environment 59, 461-475.

Kvande, T., Lis $\varnothing$, K.R., 2009. Climate adapted design of masonry structures. Building and Environment 44, 2442-2450.

LAEI, 2006. London Atmospheric Emission Inventory. Modelled PM10 Exceedance Days 2010 Values, Download from: http://data.london.gov.uk/datastore/package/laei-2006-modelledpm2010-exceedance-days-2010-values.

Larsen, P.H., Goldsmith, S., Smith, O., Wilson, M.L., Strzepek, K., Chinowsky, P., Saylor, B., 2008. Estimating future costs for Alaska public infrastructure at risk from climate change. Global Environmental Change 18, 442-457.

Lavery, S., Donovan, B., 2005. Flood risk management in the Thames Estuary looking ahead 100 years. Philosophical Transactions of the Royal Society A 363, 1455-1474.

Lee, D.S., Holland, M.R., Falla, N., 1996. The potential impact of ozone on materials in the U.K. Atmospheric Environment 30, 1053-1065.

Lee, D.S., Pitari, G., Grewe, V., Gierens, K., Penner, J.E., Petzold, A., Prather, M.J., Schumann, U., Bais, A., Berntsen, T., Iachetti, D., Lim, L.L., Sausen, R., 2010. Transport impacts on atmosphere and climate: Aviation. Atmospheric Environment 44, 4678-4734.

Leuenberger-Minger, A.U., Buchmann, B., Faller, M., Richner, P., Zobeli, M., 2002. Doseresponse functions for weathering steel, copper and zinc obtained from a four-year exposure programme in Switzerland. Corrosion Science 44, 675-687.

Levin, I., Naegle, T., Heinz, R., Osusko, D., Cuevas, E., Engel, A., Ilmberger, J., Langenfelds, R.L., Neininger, B., et al, 2009. Global SF6 emission estimates inferred from atmospheric observations - a test case for Kyoto reporting. Geophysical Research Abstracts 111, 7975.

Lewne, M., Cyrys, J., Meliefste, K., Hoek, G., Brauer, M., Fischer, P., Gehring, U., Heinrich, J., Brunekreef, B., Bellander, T., 2004. Spatial variation in nitrogen dioxide in three European areas. Science of the Total Environment 332, 217-230.

Lipfert, F.W., 1989. Atmospheric damage to calcareous stones: Comparison and reconciliation of recent experimental findings. Atmospheric Environment (1967) 23, 415-429.

Livingstone, R.A., 1992. Graphical Methods for examining the effects of acid rain and sulfur dioxide of carbonate stones. $7^{\text {th }}$ International Congress on Deterioration and Conservation of Stone, Lisbon, ed. J; Delgado Rodrigues, F. Henriques and F. Telmo Jeremias, 375-386.

Longhurst, J.W.S., Irwin, J.G., Chatterton, T.J., Hayes, E.T., Leksmono, N.S., Symons, J.K., 2009. The development of effects-based air quality management regimes. Atmospheric Environment 43, 64-78.

Loveridge, F.A., Spink, T.W., O'Brien, A.S., Briggs, K.M., Butcher, D., 2010. The impact of climate and climate change on infrastructure slopes, with particular reference to southern England. Quarterly Journal of Engineering Geology and Hydrogeology 43, 461-472.

Lu, Z., Zhang, Q., Streets, D.G., 2011. Sulfur dioxide and primary carbonaceous aerosol emissions in China and India, 1996-2010. Atmospheric Chemistry and Physics 11, 98399864. 
Maiss, M., Steele, L.P., Francey, R.J., Fraser, P.J., Langenfelds, R.L., Trivett, N.B.A., Levin, I., 1996. Sulfur hexafluoride--A powerful new atmospheric tracer. Atmospheric Environment 30, 1621-1629.

Marinoni, N., Birelli, M.P., Rostagno, C., Pavese, A., 2003. The effects of atmospheric multipollutants on modern concrete. Atmospheric Environment 37, 4701-4712.

Mavroidis, I., Chaloulakou, A., 2011. Long-term trends of primary and secondary $\mathrm{NO}_{2}$ production in the Athens area. Variation of the $\mathrm{NO}_{2} / \mathrm{NO}_{\mathrm{x}}$ ratio. Atmospheric Environment 45, 6872-6879.

McCabe, S., Smith, B., Adamson, C., Mullan, D., D., M., 2011. The "Greening” of Natural Stone Buildings: Quartz Sandstone Performance as a Secondary Indicator of Climate Change in the British Isles? Atmospheric and Climate Sciences 1, 165-171.

McIlgorm, A., Hanna, S., Knapp, G., Le Floc'H, P., Millerd, F., Pan, M., 2010. How will climate change alter fishery governance[glottal stop] Insights from seven international case studies. Marine Policy 34, 170-177.

Messafer, T., 2008. The effects of climate change on earthwork slopes. Highways Agency Project No 5703/CV/HIG, Loughborough University, UK.

Metroeconomica, 2004. Costing the impacts of climate change in the UK: overview of guidelines. UKCIP Technical Report, UK Climate Impacts Programme, Oxford, UK.

Meyer, M.D., 2006. Design standards for U.S. transportation infrastructure: the implications of climate change. Georgia Institute of Technology, Transportation Research Board Special Report 290, USA.

Mills, B., Audrey, J., 2002. Climate change and transportation: potential interactions and impacts. Proceedings of Workshop: The Potential Impact of Climate Change on Transportation, Washington D.C., U.S. Department of Transportation.

Nagpure, A.K., Gurjar, B.R., Kumar, P., 2011. Impact of altitude on emission rates of ozone precursors from gasoline-driven light-duty commercial vehicles. Atmospheric Environment 45, 1413-1417.

Nakicenovic, N., Alcamo, J., Davis, G., de Vries, B., Fenhann, J., Gaffin, S., Gregory, K., Grubber, A., Jung, T.Y., Kram, T., Rovere, E.L.L., Michaelis, L., Mori, S., Morita, T., Pepper, W., Pitcher, H., Price, L., Riahi, K., Roehrl, A., Rogner, H-H., Sankovski, A., Schlesinger, M., Shukla, P., Smith, S., Swart, R., van Rooijen, S., Victor, N., Dadi, Z., 2000. Special Report on Emissions Scenarios. Cambridge University Press, Cambridge, UK, pp. 570.

Nayar, A., 2009. Climate: When the ice melts. Nature 461, 1042-1046.

Network Rail, 2009. Network Rail Limited, Interim financial statements, six months ended 30 September 2009. Download from: http://www.networkrail.co.uk/browse\%20documents /interim\%20results/2009-10\%20network\%20rail\%20limited\%20interim\%20financial\%20statements.pdf.

Nicholls, R.J., 2004. Coastal flooding and wetland loss in the 21st century: changes under the SRES climate and socio-economic scenarios. Global Environmental Change 14, 69-86.

Nicholls, R.J., Hanson, S., Herweijer, C., Patmore, N., Hallegatte, S., Corfee-Morlot, J., Chateau, J., Muir-Wood, R., 2007. Ranking port cities with high exposure and vulnerability to climate extremes: exposure estimates. Environment Working Papers No 1 Environment Directorate, Organisation for Economic Co-operation and Development (OECD).

Nijland, T.G., Adan, O.C.G., Hees, C.G.A., vanHees, R.P.J., van Etten, B.D., 2009. Evaluation of the effects of expected climate change on the durability of building materials with suggestion for adaptation. Heron 54, 37-48.

Noah's Ark, 2006. Global climate change impact on built heritage and cultural landscapes. Overview of the expected negative and positive consequences of global environmental changes on deterioration of materials. Project Report No. SPPI-CT-2003-501837-NOAH'S ARK. 
Ozga, I., Bonazza, A., Bernardi, E., Tittarelli, F., Favoni, O., Ghedini, N., Morselli, L., Sabbioni, C., 2011. Diagnosis of surface damage induced by air pollution on 20th-century concrete buildings. Atmospheric Environment 45, 4986-4995.

Papadakis, V.G., Fardis, M.N., Vayenas, G.G., 1992. Effect of composition, environmental factors and cement-lime coating on concrete carbonation. Material and Structure 25, 293304.

Pejovic, T., Williams, V.A., Noland, R.B., Toumi, R., 2009. Factors affecting the frequency and severity of airport weather delays and the implications of climate change for future delays. Transportation Research Record: Journal of the Transportation Research Board 2139, 97-106.

Peng, J., Stewart, M.G., 2008. Carbonation-induced corrosion damage and structural safety for concrete structures under enhanced greenhouse conditions. Centre for Infrastructure Performance and Reliability Research Report No. 270.11.2008, ISBN No. 978098050355 9785.

Peter, M.A., Muntean, A., Meier, S.A., Böhm, M., 2008. Competition of several carbonation reactions in concrete: A parametric study. Cement and Concrete Research 38, 1385-1393.

Peterson, T.C., McGuirk, M., Houston, T.G., Horvitz, A.H., Wehner, M.F., 2006. Climate variability and change with implications for transportation, Lawrence Berkeley National Laboratory. Transportation Research Board Special Report 290, USA.

PIANC, 2008. Waterborne transport, ports and waterways: A review of climate change drivers, impacts, responses and mitigation. Report of PIANC EnviCom Task Group 3, Climate change and navigation, PIANC, Brussels, Belgium.

Prather, M., Gauss, M., Berntsen, T., Isaksen, I., Sundet, J., Bey, I., Brasseur, G., Dentener, F., Derwent, R., Stevenson, D., Grenfell, L., Hauglustaine, D., Horowitz, L., Jacob, D., Mickley, L., Lawrence, M., von Kuhlmann, R., Muller, J.-F., Pitari, G., Rogers, H., Johnson, M., Pyle, J., Law, K., van Weele, M., Wild, O., 2003. Fresh air in the 21st century? Geophysical Research Letters 30, 1100, doi:10.1029/2002GL016285

RAEng, 2011. Royal Academy of Engineering, Infrastructure, Engineering and Climate Change Adaptation - ensuring services in an uncertain future. London.

Ramanathan, V., Feng, Y., 2009. Air pollution, greenhouse gases and climate change: Global and regional perspectives. Atmospheric Environment 43, 37-50.

Ravishankara, A.R., Solomon, S., Turnipseed, A.A., F., W.R., 1993. Atmospheric lifetimes of long-lived halogenated species. Science 259, 194-199.

Ross, K., Saunders, G., Novakovic, O., 2007. Climate change and innovation in house building, Designing out risk. NHBC Foundation, UK ISBN: 978-1-86081-987-2.

RSSB, 2003. Rail Safety and Standards Board, Safety Implications of Weather, Climate and Climate Change: Final Report. Report No AEAT/RAIR/76148/R03/005, Cheshire, UK.

Sabboni, C., Cassar, M., Brimblecombe, P., Tidblad, J., Kozlowski, R., Drdacky, M., SaizJimenez, C., Grontoft, T., Wainwright, I., Arino, X., 2006. Global climate change impact on building heritage and cultural landscapes. Heritage, Weathering and Conservation Fort, Alvarez de Buergo, Gomez-Heras \& Vazquez-Calvo (eds) ISBN 0-415-41272-2, 395401.

Sanders, C.H., Phillipson, M.C., 2003. UK adaptation strategy and technical measures: the impacts of climate change on buildings. Building Research \& Information 31, 210-221.

Scheffer, T.C., 1971. A climate index for estimating potential for decay in wood structures above ground. Forest Products Journal 21, 25-31.

Screpanti, A., De Marco, A., 2009. Corrosion on cultural heritage buildings in Italy: A role for ozone? Environmental Pollution 157, 1513-1520.

Shang, H., Song, Y., Ou, J., 2009. Behavior of air-entrained concrete after freeze-thaw cycles. Acta Mechanica Solida Sinica 22, 261-266.

Söderholm, P., Pettersson, F., 2008. Climate policy and the social cost of power generation: Impacts of the Swedish national emissions target. Energy Policy 36, 4154-4158.

Stansfield, K., 2001. Global warming: issues for engineers. The Structural Engineer 79, 13-14. 
Stern, D.I., 2005. Global sulfur emissions from 1850 to 2000. Chemosphere 58, 163-175.

Stern, N., 2007. The Stern Review: the Economics of Climate Change. Cambridge University Press, Cambridge January.

Stern, N., Peters, S., Bakhshi, V., Bowen, A., Cameron, C., Catovsky, S., Crane, D., Cruickshank, S., Dietz, S., Edmonson, N., Garbett, S.-L., Hamid, L., Hoffman, G., Ingram, D., Jones, B., Patmore, N., Radcliffe, H., Sathiyarajah, R., Stock, M., Taylor, C., Vernon, T., Wanjie, H., Zenghelis, D., 2006. Stern Review: the Economics of Climate Change. HM Treasury, London.

Stewart, M.G., Wang, X., Nguyen, M.N., 2011. Climate change impacts and risks of concrete infrastructure deterioration. Engineering Structures 33, 1326-1337.

Stimpson, J., 2009. Cumbria flooding exposes UK's vulnerability to infrastructure failure. New Civil Engineer. Download from: http:// www.nce.co.uk/home/water/cumbria-floodingexposes-uks-vulnerability-to-infrastructure-failure/5211340.article.

Suarez, P., Anderson, W., Mahal, V., Lakshmanan, T.R., 2005. Impacts of flooding and climate change on urban transportation: a systemwide performance assessment of the Boston Metro Area. Transportation Research Part D: Transport and Environment 10, 231-244.

Sutherland, J., Gouldby, B., 2003. Vulnerability of coastal defences to climate change. Proceedings of the Institution of Civil Engineers: Water and Maritime Engineering 156, 137-145.

Sweeney, C., 2009. Hundreds of homes evacuated as flooding causes chaos in Scotland's North East. Times Online. Download from: http://www.timesonline.co.uk/tol/news/uk/scotland/ article6822075.ece?token $=$ null\&offset $=0 \&$ page $=1$.

Texte 24/99, 1999. Quantification of effects of air pollutants on materials. Proceedings of the UN/ECE Workshop on quantification of effects of air pollutants on materials, Umweltbundesamt, Berlin, May 1999.

Tidblad, J., 2007. Air pollution and its relations to climate change and sustainable development - Linking immediate needs with long term challanges. Saltsjöbaden 3 12-14 March 2007, Gothenburg, Sweden.

Tidblad, J., 2012. Atmospheric corrosion of metals in 2010-2039 and 2070-2099. Atmospheric Environment 55, 1-6.

Tidblad, J., Kucera, V., Mikhailov, A., Henriksen, J., Kreislova, K., Yates, T., Stöckle, B., Schreiner, M., 2001. UN ECE ICP Materials: Dose-response functions on dry and wet acid deposition effects after 8 years of exposure. Water, Air, \& Soil Pollution 130, 1457-1462.

Tonoli, G.H.D., Santos, S.F., Joaquim, A.P., Savastano Jr, H., 2010. Effect of accelerated carbonation on cementitious roofing tiles reinforced with lignocellulosic fibre. Construction and Building Materials 24, 193-201.

TRB, 2008. Transportation Research Board, Potential impacts of climate change on U.S. Transportation. Transportation Research Board Special Report 290. Committee on Climate Change and U.S. Transportation, National Research Council, Washington D.C.

UKCIP, 2003. UK Climate Impacts Programme. Building knowledge for a changing climate. The impacts of climate change on the built environment - a research agenda Engineering and Physical Sciences Research Council (EPSRC).

UKCP09, 2009. UK Climate Projections. Department for Environment, Food and Rural Affairs (Defra), UK, Download from: http://ukclimateprojections.defra.gov.uk/

UN, 2008. ICP Materials Technical Document. Combined effects of climate change and air pollution on materials including cultural heritage ECE/EB.AIR/WG.1/2008/8, pp. 12.

UNEP, 2007. Buildings and climate change: status, challenges and opportunities. United Nations Environment Programme ISBN: 978-92-807-2795-1.

Varotsos, C., C., T., Cracknell, A., 2009. The enhanced deterioration of the cultural heritage monuments due to air pollution. Environmental Science and Pollution Research 16, 590592. 
Vardoulakis, S., Heaviside, C. (editors). 2012. Health effects of climate change in the UK 2012: Current evidence, recommendations and research gaps. Health Protection Agency, UK, pp. 242. Download: http://www.hpa.org.uk/webc/HPAwebFile/HPAweb_C/1317135969235.

Vega-Leinert de la, A.C., Nicholls, R.J., 2008. Potential implications of sea-level rise for Great Britain. Journal of Coastal Research 24, 342-357.

Vincent, W.F., Gene, E.L., 2009. Effects of climate change on lakes. Encyclopedia of Inland Waters. Academic Press, Oxford, pp. 55-60.

Walsh, C.L., Hall, J.W., Street, R.B., Blanksby, J., Cassar, M., Ekins, P., Glendinning, S., Goodess, C.M., Handley, J., Noland, R., Watson, S.J., 2007. Building knowledge for a changing climate: collaborative research to understand and adapt to the impacts of climate change on infrastructure, the built environment and utilities. Newcastle University, UK.

Walters, C., 2009. The effects of climate change on 3CAP's highway network policies and standards. The 3 Counties Alliance Partnership (3CAP), Scott Wilson, U.K.

Ward, P.L., 2009. Sulfur dioxide initiates global climate change in four ways. Thin Solid Films 517, 3188-3203.

Wardhana, K., Hadipriono, F.C., 2003. Analysis of recent bridge failures in the United States. ASCE Journal of Performance of Constructed Facilities 17, 144-150.

West, C.C., Gawith, M.J., 2005. Measuring progress: Preparing for climate change through the UK Climate Impacts Programme. UKCIP Technical Report, Oxford ISBN: 0-9544930-5-7.

Willway, T., Baldachin, L., Reeves, S., Harding, M., 2008. The effects of climate change on highway pavements and how to minimise them. Technical report. Transport Research Laboratory, UK ISBN: 978-1-84608-734-9.

Yoon, I.-S., Çopuroglu, O., Park, K.-B., 2007. Effect of global climatic change on carbonation progress of concrete. Atmospheric Environment 41, 7274-7285.

Zeng, G., Morgenstern, O., Braesicke, P., Pyle, J.A., 2010. Impact of stratospheric ozone recovery on tropospheric ozone and its budge. Geophysical Research Letters 37, L09805. doi:10.1029/2010GL042812 


\section{List of Figure captions}

1480 Fig. 1. Integrated impacts and interactions of air pollutants and climate parameters on 1481 built infrastructure.

1482 Fig. 2 (a) Total $\mathrm{CO}_{2}$-equivalent emissions of different anthropogenic gases in 2004; $1483 \mathrm{CO}_{2}$ include emissions from fossil fuel use (56.6\%), deformation and decay of biomass $1484(17.3 \%)$ and other sources $(2.8 \%)$ whereas $\mathrm{F}$-gases include fluorocarbons such as 1485 HFCs, PFCs and $\mathrm{SF}_{6}$, and (b) $\mathrm{CO}_{2}$-equivalent share of total anthropogenic GHGs 1486 emissions in 2004 from different sectors (IPCC, 2007); $\mathrm{CO}_{2}$-equivalent concentration is 1487 defined as the concentration of $\mathrm{CO}_{2}$ that would cause the same amount of radiative 1488 forcing as a given mixture of $\mathrm{CO}_{2}$ and other forcing components.

1489 Fig. 3. Estimates of annual surface recession and material loss in London during 1990 1490 and 2010 for (a) limestone, (b) carbon steel, (c) zinc, and (d) copper.

1491 Fig. 4. Effect of changing environmental conditions on thickness loss of carbon steel. 


\section{$1493 \quad$ List of Tables}

1494 Table 1. Corrosion sensitivity of various materials towards air pollutants and climate 1495 parameters. The list is compiled based on the various DRFs proposed in the literature 1496 (Kucera and Fitz, 1995; Kucera et al., 2007; Leuenberger-Minger et al., 2002; Noah's 1497 Ark, 2006; Scheffer, 1971; Screpanti and De Marco, 2009; Tidblad et al., 2001).

\begin{tabular}{|c|c|c|c|c|c|c|c|c|}
\hline Material & $\mathrm{SO}_{2}$ & $\mathrm{O}_{3}$ & $\mathrm{NO}_{2}$ & $\mathrm{PM}_{10}$ & $\mathrm{Rh}$ & $\operatorname{Rain}\left[\mathrm{H}^{+}\right]$ & Rain $\left[\mathrm{Cl}^{-}\right]$ & Temp \\
\hline Weathering steel & $\otimes$ & $\otimes$ & & $\otimes$ & $\otimes$ & & & $\otimes$ \\
\hline Carbon steel & $\otimes$ & $\otimes$ & & $\otimes$ & $\otimes$ & & & $\otimes$ \\
\hline Limestone & $\otimes$ & $\otimes$ & $\otimes$ & $\otimes$ & $\otimes$ & $\otimes$ & & $\otimes$ \\
\hline Sandstone & $\otimes$ & & & & $\otimes$ & $\otimes$ & & $\otimes$ \\
\hline Zinc & $\otimes$ & $\otimes$ & & & $\otimes$ & $\otimes$ & & $\otimes$ \\
\hline Aluminium & $\otimes$ & & & & $\otimes$ & & $\otimes$ & $\otimes$ \\
\hline Copper & $\otimes$ & $\otimes$ & & & $\otimes$ & $\otimes$ & & $\otimes$ \\
\hline Cast Bronze & $\otimes$ & $\otimes$ & & & & $\otimes$ & $\otimes$ & $\otimes$ \\
\hline Glass & $\otimes$ & & $\otimes$ & & & & & $\otimes$ \\
\hline Paint/galvanised & $\otimes$ & & & & & & & $\otimes$ \\
\hline Paint/steel & $\otimes$ & & & & & & & $\otimes$ \\
\hline Nickel & $\otimes$ & $\otimes$ & & & & & & $\otimes$ \\
\hline Tin & & $\otimes$ & & & & & & $\otimes$ \\
\hline $\begin{array}{l}\text { Rubber and plastic } \\
\text { materials }\end{array}$ & & $\otimes$ & & & & & & $\otimes$ \\
\hline Lead & & & & & $\otimes$ & & & $\otimes$ \\
\hline Wood & & & & & & $\otimes$ & $\otimes$ & $\otimes$ \\
\hline Concrete & $\otimes$ & & $\otimes$ & & $\otimes$ & $\otimes$ & $\otimes$ & $\otimes$ \\
\hline
\end{tabular}


1500 Table 2. GHGs and their global warming potential (Forster et al., 2007; IPCC, 2007;

1501 Ravishankara et al., 1993; UNEP, 2007).

1502

\begin{tabular}{llllll}
\hline GHGs & $\begin{array}{l}\text { Global mean } \\
\text { Concentrations } \\
\text { in 2005 }(\mathrm{ppm})\end{array}$ & $\begin{array}{l}\text { Atmospheric } \\
\text { life time } \\
(\sim \text { years })\end{array}$ & $\begin{array}{l}\text { Change } \\
\text { since 1998 } \\
(\mathrm{ppm})\end{array}$ & $\begin{array}{l}\text { Radiative } \\
\text { forcing }(\mathrm{W} \\
\left.\mathrm{m}^{-2}\right)\end{array}$ & $\begin{array}{l}\text { GWP for 100- } \\
\text { year time with } \\
\text { respect to } \mathrm{CO}_{2}\end{array}$ \\
\hline $\mathrm{CO}_{2}$ & $379 \pm 0.65$ & 500 & +13 & 1.66 & 1 \\
$\mathrm{CH}_{4}$ & $1.774 \pm 0.0018$ & 12 & +0.011 & 0.48 & 25 \\
$\mathrm{~N}_{2} \mathrm{O}$ & $0.319 \pm 0.00012$ & 114 & +0.005 & 0.16 & 298 \\
$\mathrm{CFCs}^{\mathrm{b}}$ & $868 \pm 0.604$ & $45-640$ & -13 & 0.257 & $4,750-6130$ \\
$\mathrm{SF}_{6}{ }^{\mathrm{b}}$ & $5.6 \pm 0.038$ & up to 3200 & +1.5 & 0.0029 & 22,800
\end{tabular}

$1503{ }^{a}$ Accepted value range though this is variable and can be estimated by the formulae 1504 given in foot note 'a' on page 213 of the IPPC (2007) report.

$1505{ }^{\mathrm{b}} \mathrm{CFC}$ include combined net values (in ppt) of CFC-11, CFC-12 and CFC-113. SF 6 1506 values are in ppt. 
Table 3. List of DRFs for various materials in unsheltered conditions. Both Tidblad et al. (2001) and Screpanti and De Marco (2009) gives DRFs for 8-year exposure. DRFs given by Leuenberger-Minger et al. (2002) and Noah's Ark (2006) are for 4 and 1 year exposure, respectively. ML, LL and $\mathrm{R}$ stand for mass loss by corrosion attack in $\mathrm{g} \mathrm{m}^{-2}$, leached layer in $\mathrm{nm}$, surface recession or thickness loss in $\mu \mathrm{m}(>1$-year exposure) or $\mu \mathrm{m} \mathrm{yr}^{-1}$ (1-year exposure), respectively. Gaseous and ion concentrations are annual mean in $\mu \mathrm{g} \mathrm{m}^{-3}$ and $\mathrm{mg} \mathrm{lit}^{-1}$. $D_{\mathrm{cl}}$ is chloride deposition $\left(\mathrm{mg} \mathrm{m}^{-2}\right.$ day $\left.^{-1}\right)$ and $\mathrm{Rh}_{60}=(\mathrm{Rh}-$ 60) when $\mathrm{Rh}>60$; otherwise 0 . $\mathrm{Rn}$ is precipitation in $\mathrm{m} \mathrm{yr}^{-1} ; V_{\mathrm{dS}}$ and $V_{\mathrm{dN}}$ are deposition velocities $\left(\mathrm{cm} \mathrm{s}^{-1}\right)$ for $\mathrm{SO}_{2}$ and $\mathrm{HNO}_{3}$, respectively.

\begin{tabular}{|c|c|c|}
\hline Material & Dose-response function & Source \\
\hline \multirow[t]{2}{*}{ Weathering steel } & 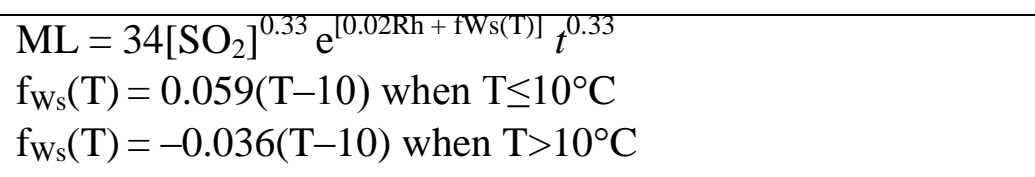 & $\begin{array}{l}\text { Tidblad et al. } \\
\text { (2001) }\end{array}$ \\
\hline & $\begin{array}{l}{ }^{\mathrm{a}} \mathrm{R}=1.92+2.97\left[\mathrm{SO}_{2}\right] t_{\mathrm{ow}} t^{0.37}+0.89\left[\mathrm{SO}_{2}\right] t_{\mathrm{ow}} u t^{0.37}+ \\
0.15\left[\mathrm{O}_{3}\right] t^{0.37}\end{array}$ & $\begin{array}{l}\text { Leuenberger- } \\
\text { Minger et al. } \\
\text { (2002) }\end{array}$ \\
\hline \multirow[t]{3}{*}{ Carbon steel } & $\begin{array}{l}\mathrm{R}=1.58\left[\mathrm{SO}_{2}\right]^{0.52} \mathrm{e}^{[0.02 \mathrm{Rh}+\mathrm{fCs}(\mathrm{T})]}+0.166 \mathrm{Rn}\left[\mathrm{H}^{+}\right]+0.0761 \\
\mathrm{PM}_{10}+0.102 \mathrm{D}_{\mathrm{Cl}}^{0.33} \mathrm{e}^{[0.033 \mathrm{Rh}+0.040 \mathrm{~T}]} \\
\mathrm{f}_{\mathrm{Cs}}(\mathrm{T})=0.150(\mathrm{~T}-10) \text { when } \mathrm{T} \leq 10^{\circ} \mathrm{C} \\
\mathrm{f}_{\mathrm{Cs}}(\mathrm{T})=-0.054(\mathrm{~T}-10) \text { when } \mathrm{T}>10^{\circ} \mathrm{C}\end{array}$ & $\begin{array}{l}\text { Noah's Ark } \\
(2006)\end{array}$ \\
\hline & $\begin{array}{l}\mathrm{R}=1.77[\mathrm{SO} 2]^{0.52} \mathrm{e}^{[0.20 \mathrm{Rh}+\mathrm{fws}(\mathrm{T})]}+\mathrm{g}\left(\mathrm{Cl}^{-}, \mathrm{Rh}, \mathrm{T}\right) \\
\mathrm{ML}=29.1+t^{0.6}\left(21.7+1.39\left[\mathrm{SO}_{2}\right]^{0.6} \mathrm{Rh}_{60} \mathrm{e}^{\mathrm{fWs}(\mathrm{T})}+1.29\right. \\
\left.\mathrm{Rn}\left[\mathrm{H}^{+}\right]+0.593 \mathrm{PM}_{10}\right) \\
\mathrm{F}_{\mathrm{Cs}}(\mathrm{T})=0.150(\mathrm{~T}-10) \text { when } \mathrm{T} \leq 10^{\circ} \mathrm{C} \\
\mathrm{F}_{\mathrm{Cs}}(\mathrm{T})=-0.054(\mathrm{~T}-10) \text { when } \mathrm{T}>10^{\circ} \mathrm{C} \\
\mathrm{g}\left(\mathrm{Cl}{ }^{-}, \mathrm{Rh}, \mathrm{T}\right) \text { is a function describing the dry deposition } \\
\text { effect of chloride in combination with Rh and } \mathrm{T}\end{array}$ & $\begin{array}{l}\text { Kucera et al. } \\
(2007)\end{array}$ \\
\hline & $R=13.4 t^{0.98}\left(\frac{t_{o w}}{3800}\right)^{0.46}\left(1+\frac{\left[S O_{2}\right]}{25}\right)^{0.62}\left(1+\frac{\left[D_{c l}\right]}{50}\right)^{0.34} e^{0.016(T+20)}$ & $\begin{array}{l}\text { Klinesmith et al. } \\
(2007)\end{array}$ \\
\hline $\begin{array}{l}\text { Steel panels with } \\
\text { alkyde (fresh } \\
\text { samples) }\end{array}$ & $\begin{array}{l}\mathrm{ML}=\left(0.033\left[\mathrm{SO}_{2}\right]+0.013 \mathrm{Rh}+\mathrm{f}_{\mathrm{Sp}}(\mathrm{T})+0.0013 \mathrm{Rn}\left[\mathrm{H}^{+}\right]\right) \\
t^{0.41} \\
\mathrm{f}_{\mathrm{Sp}}(\mathrm{T})=0.015(\mathrm{~T}-11) \text { when } \mathrm{T} \leq 11^{\circ} \mathrm{C} \\
\mathrm{f}_{\mathrm{Sp}}(\mathrm{T})=-0.15(\mathrm{~T}-11) \text { when } \mathrm{T}>11^{\circ} \mathrm{C}\end{array}$ & $\begin{array}{l}\text { Tidblad et al. } \\
\text { (2001) }\end{array}$ \\
\hline
\end{tabular}




\begin{tabular}{|c|c|c|}
\hline $\begin{array}{l}\text { Coil coated } \\
\text { galvanised steel } \\
\text { with alkyd } \\
\text { melamine (fresh } \\
\text { samples) }\end{array}$ & $\begin{array}{l}\mathrm{ML}=\left(0.0084\left[\mathrm{SO}_{2}\right]+0.015 \mathrm{Rh}+\mathrm{f}_{\mathrm{Cc}}(\mathrm{T})+0.00082 \mathrm{Rn}\left[\mathrm{H}^{+}\right]\right) \\
t^{0.43} \\
\mathrm{f}_{\mathrm{Cc}}(\mathrm{T})=0.040(\mathrm{~T}-10) \text { when } \mathrm{T} \leq 10^{\circ} \mathrm{C} \\
\mathrm{f}_{\mathrm{Cc}}(\mathrm{T})=-0.064(\mathrm{~T}-10) \text { when } \mathrm{T}>10^{\circ} \mathrm{C}\end{array}$ & $\begin{array}{l}\text { Tidblad et al. } \\
\text { (2001) }\end{array}$ \\
\hline \multirow[t]{5}{*}{$\begin{array}{l}\text { Portland } \\
\text { limestone }\end{array}$} & $\mathrm{R}=2.7\left[\mathrm{SO}_{2}\right]^{0.48} \mathrm{e}^{-0.018 \mathrm{~T}} t^{0.96}+0.019 \mathrm{Rn}\left[\mathrm{H}^{+}\right] t^{0.96}$ & $\begin{array}{l}\text { Tidblad et al. } \\
\text { (2001) }\end{array}$ \\
\hline & $\begin{array}{l}\mathrm{R}=3.1+t\left(0.85+0.0059 \mathrm{Rh}_{60}\left[\mathrm{SO}_{2}\right]+0.078 \mathrm{Rh}_{60}\left[\mathrm{HNO}_{3}\right]\right. \\
\left.+0.054 \mathrm{Rn}\left[\mathrm{H}^{+}\right]+0.0258 \mathrm{PM}_{10}\right)\end{array}$ & $\begin{array}{l}\text { Kucera et al. } \\
(2007)\end{array}$ \\
\hline & {$\left[\mathrm{HNO}_{3}\right]=516 \mathrm{e}^{-3400 /(\mathrm{T}+273)}\left(\left[\mathrm{NO}_{2}\right]\left[\mathrm{O}_{3}\right] \mathrm{Rh}\right)^{0.5}$} & \\
\hline & $\begin{array}{l}\mathrm{R}=18.8 \mathrm{Rn}+0.016[\mathrm{H}+] \mathrm{Rn}+0.18\left(V_{\mathrm{dS}}[\mathrm{SO} 2]+V_{\mathrm{dN}}\right. \\
\left.\left[\mathrm{HNO}_{3}\right]\right)\end{array}$ & Lipfert (1989) \\
\hline & $\begin{array}{l}{ }^{\mathrm{c}} \mathrm{R}=3.1+t\left(0.85+0.0059\left[\mathrm{SO}_{2}\right] \mathrm{Rh}_{60}+0.054 \mathrm{Rn}\left[\mathrm{H}^{+}\right]+\right. \\
0.078\left(516 \mathrm{e}^{-3400 /(\mathrm{T}+273)}\left(\left[\mathrm{NO}_{2}\right]\left[\mathrm{O}_{3}\right] \mathrm{Rh}\right)^{0.5} \mathrm{Rh}_{60}\right)+0.0258 \\
\left.\mathrm{PM}_{10}\right)\end{array}$ & $\begin{array}{l}\text { Screpanti and De } \\
\text { Marco (2009) }\end{array}$ \\
\hline $\begin{array}{l}\text { White Mansfield } \\
\text { sandstone }\end{array}$ & $\begin{array}{l}\mathrm{R}=\left(2\left[\mathrm{SO}_{2}\right]^{0.52} \mathrm{e}^{\mathrm{fMs}(\mathrm{T})}+0.028 \mathrm{Rain}\left[\mathrm{H}^{+}\right]\right) \mathrm{t}^{0.91} \\
\mathrm{f}_{\mathrm{Ms}}(\mathrm{T})=0 \text { when } \mathrm{T} \leq 10^{\circ} \mathrm{C} \\
\mathrm{f}_{\mathrm{Ms}}(\mathrm{T})=-0.013(\mathrm{~T}-10) \text { when } \mathrm{T}>10^{\circ} \mathrm{C}\end{array}$ & $\begin{array}{l}\text { Tidblad et al. } \\
\text { (2001) }\end{array}$ \\
\hline \multirow[t]{5}{*}{ Zinc } & $\begin{array}{l}\mathrm{ML}=1.4\left[\mathrm{SO}_{2}\right]^{0.22} \mathrm{e}^{[0.018 \mathrm{Rh}+\mathrm{fZn}(\mathrm{T})]} t^{0.85}+0.029 \mathrm{Rn}\left[\mathrm{H}^{+}\right] t \\
\mathrm{f}_{\mathrm{Zn}}(\mathrm{T})=0.062(\mathrm{~T}-10) \text { when } \mathrm{T} \leq 10^{\circ} \mathrm{C} \\
\mathrm{f}_{\mathrm{Zn}}(\mathrm{T})=-0.021(\mathrm{~T}-10) \text { when } \mathrm{T}>10^{\circ} \mathrm{C}\end{array}$ & $\begin{array}{l}\text { Tidblad et al. } \\
(2001)\end{array}$ \\
\hline & $\begin{array}{l}\mathrm{ML}=1.82+t\left(1.71+0.471\left[\mathrm{SO}_{2}\right]^{0.22} \mathrm{e}^{[0.018 \mathrm{Rh}+\mathrm{fZn}(\mathrm{T})]}+\right. \\
\left.0.041 \mathrm{Rn}\left(\mathrm{H}^{+}\right)+1.37\left[\mathrm{HNO}_{3}\right]\right) \\
\mathrm{f}_{\mathrm{Zn}}(\mathrm{T})=0.062(\mathrm{~T}-10) \text { when } \mathrm{T} \leq 10^{\circ} \mathrm{C} \\
\mathrm{f}_{\mathrm{Zn}}(\mathrm{T})=-0.021(\mathrm{~T}-10) \text { when } \mathrm{T}>10^{\circ} \mathrm{C}\end{array}$ & $\begin{array}{l}\text { Kucera et al. } \\
(2007)\end{array}$ \\
\hline & $\begin{array}{l}{ }^{\mathrm{a}} \mathrm{R}=0.33+0.38\left[\mathrm{SO}_{2}\right] t_{\mathrm{ow}} u t^{0.53}-0.5\left[\mathrm{SO}_{2}\right] t_{\mathrm{ow}}\left[\mathrm{O}_{3}\right] t^{0.53}+ \\
0.00007[\mathrm{SO} 2]\left[\mathrm{O}_{3}\right] \mathrm{Rh} t^{0.53}\end{array}$ & $\begin{array}{l}\text { Leuenberger- } \\
\text { Minger et al. } \\
(2002)\end{array}$ \\
\hline & $\begin{array}{l}\mathrm{R}=0.196\left[\mathrm{SO}_{2}\right]^{0.22} \mathrm{e}^{[0.018 \mathrm{Rh}+\mathrm{fZn}(\mathrm{T})]}+0.00406 \mathrm{Rn}\left[\mathrm{H}^{+}\right]+ \\
0.192\left[\mathrm{HNO}_{3}\right]+0.0175 D_{\mathrm{Cl}}^{0.57} \mathrm{e}^{[0.008 \mathrm{Rh}+0.085 \mathrm{~T}]} \\
\mathrm{f}_{\mathrm{Zn}}(\mathrm{T})=0.062(\mathrm{~T}-10) \text { when } \mathrm{T} \leq 10^{\circ} \mathrm{C} \\
\mathrm{f}_{\mathrm{Zn}}(\mathrm{T})=-0.021(\mathrm{~T}-10) \text { when } \mathrm{T}>10^{\circ} \mathrm{C}\end{array}$ & $\begin{array}{l}\text { Noah's Ark } \\
(2006)\end{array}$ \\
\hline & $R=0.16 t^{0.36}\left(\frac{t_{o w}}{3800}\right)^{0.24}\left(1+\frac{\left[S O_{2}\right]}{25}\right)^{0.82}\left(1+\frac{\left[D_{c l}\right]}{50}\right)^{0.44} e^{0.05(T+20)}$ & $\begin{array}{l}\text { Klinesmith et al. } \\
\text { (2007) }\end{array}$ \\
\hline Aluminium & $\begin{array}{l}\mathrm{ML}=0.0021\left[\mathrm{SO}_{2}\right]^{0.23} \mathrm{Rh} \mathrm{e}^{\mathrm{fAl}(\mathrm{T})} t^{1.2}+0.000023 \mathrm{Rn}\left[\mathrm{Cl}^{-}\right] t \\
\mathrm{f}_{\mathrm{Al}}(\mathrm{T})=0.031(\mathrm{~T}-10) \text { when } \mathrm{T} \leq 10^{\circ} \mathrm{C} \\
\mathrm{f}_{\mathrm{Al}}(\mathrm{T})=-0.61(\mathrm{~T}-10) \text { when } \mathrm{T}>10^{\circ} \mathrm{C}\end{array}$ & $\begin{array}{l}\text { Tidblad et al. } \\
(2001)\end{array}$ \\
\hline
\end{tabular}




\begin{tabular}{|c|c|c|}
\hline & $R=0.094 t^{0.05}\left(\frac{t_{o w}}{3800}\right)^{0.23}\left(1+\frac{\left[S O_{2}\right]}{25}\right)^{1.14}\left(1+\frac{\left[D_{c l}\right]}{50}\right)^{0.42} e^{0.01(T+20)}$ & $\begin{array}{l}\text { Klinesmith et al. } \\
\text { (2007) }\end{array}$ \\
\hline \multirow[t]{5}{*}{ Copper } & $\begin{array}{l}\mathrm{ML}=0.0027\left[\mathrm{SO}_{2}\right]^{0.32}\left[\mathrm{O}_{3}\right]^{0.79} \mathrm{Rh} \mathrm{e}^{\mathrm{fCu}(\mathrm{T})} t^{0.78}+0.050 \\
\mathrm{Rn}\left[\mathrm{H}^{+}\right] t^{0.89} \\
\mathrm{f}_{\mathrm{Cu}}(\mathrm{T})=0.083(\mathrm{~T}-10) \text { when } \mathrm{T} \leq 10^{\circ} \mathrm{C} \\
\mathrm{f}_{\mathrm{Cu}}(\mathrm{T})=-0.032(\mathrm{~T}-10) \text { when } \mathrm{T}>10^{\circ} \mathrm{C}\end{array}$ & $\begin{array}{l}\text { Tidblad et al. } \\
\text { (2001) }\end{array}$ \\
\hline & $\begin{array}{l}\mathrm{ML}=3.12+t\left(1.09+0.00201\left[\mathrm{SO}_{2}\right]^{0.4}\left[\mathrm{O}_{3}\right] \mathrm{Rh}_{60} \mathrm{e}^{\mathrm{fCu}(\mathrm{T})}+\right. \\
\left.0.0878 \mathrm{Rn}\left[\mathrm{H}^{+}\right]\right) \\
\mathrm{f}_{\mathrm{Cu}}(\mathrm{T})=0.083(\mathrm{~T}-10) \text { when } \mathrm{T} \leq 10^{\circ} \mathrm{C} \\
\mathrm{f}_{\mathrm{Cu}}(\mathrm{T})=-0.032(\mathrm{~T}-10) \text { when } \mathrm{T}>10^{\circ} \mathrm{C}\end{array}$ & $\begin{array}{l}\text { Kucera et al. } \\
(2007)\end{array}$ \\
\hline & $\begin{array}{l}{ }^{\mathrm{a}} \mathrm{R}=0.1+0.2\left[\mathrm{SO}_{2}\right] t_{\mathrm{ow}} t^{0.41}+0.0044\left[\mathrm{SO}_{2}\right]\left[\mathrm{O}_{3}\right] t^{0.41}+ \\
0.016\left[\mathrm{O}_{3}\right] t^{0.41}\end{array}$ & $\begin{array}{l}\text { Leuenberger- } \\
\text { Minger et al. } \\
(2002)\end{array}$ \\
\hline & $\begin{array}{l}\mathrm{R}=0.000302\left[\mathrm{SO}_{2}\right]^{0.32}\left[\mathrm{O}_{3}\right]^{0.79} \mathrm{Rh} \mathrm{e}^{\mathrm{fCu}(\mathrm{T})}+0.00560 \mathrm{Rn}\left[\mathrm{H}^{+}\right] \\
+0.0125 D_{\mathrm{Cl}}^{0.27} \mathrm{e}^{[0.036 \mathrm{Rh}+0.049 \mathrm{~T}]} \\
\mathrm{f}_{\mathrm{Cu}}(\mathrm{T})=0.083(\mathrm{~T}-10) \text { when } \mathrm{T} \leq 10^{\circ} \mathrm{C} \\
\mathrm{f}_{\mathrm{Cu}}(\mathrm{T})=-0.032(\mathrm{~T}-10) \text { when } \mathrm{T}>10^{\circ} \mathrm{C}\end{array}$ & $\begin{array}{l}\text { Noah's Ark } \\
\text { (2006) }\end{array}$ \\
\hline & $R=0.46 t^{0.15}\left(\frac{t_{o w}}{3800}\right)^{0.02}\left(1+\frac{\left[S O_{2}\right]}{25}\right)^{0.38}\left(1+\frac{\left[D_{c l}\right]}{50}\right)^{0.46} e^{0.02(T+20)}$ & $\begin{array}{l}\text { Klinesmith et al. } \\
\text { (2007) }\end{array}$ \\
\hline \multirow[t]{3}{*}{ Cast Bronze } & $\begin{array}{l}\mathrm{ML}=0.026\left[\mathrm{SO}_{2}\right]^{0.44} \mathrm{Rh}^{\mathrm{fBr}(\mathrm{T})} t^{0.86}+0.029 \mathrm{Rn}\left[\mathrm{H}^{+}\right] t^{0.76}+ \\
0.000043 \mathrm{Rn}\left[\mathrm{Cl}^{-}\right] t^{0.76} \\
\mathrm{f}_{\mathrm{Br}}(\mathrm{T})=0.060(\mathrm{~T}-11) \text { when } \mathrm{T} \leq 11^{\circ} \mathrm{C} \\
\mathrm{f}_{\mathrm{B}} \mathrm{r}(\mathrm{T})=-0.067(\mathrm{~T}-11) \text { when } \mathrm{T}>11^{\circ} \mathrm{C}\end{array}$ & $\begin{array}{l}\text { Tidblad et al. } \\
(2001)\end{array}$ \\
\hline & $\begin{array}{l}\mathrm{ML}=1.33+t\left(0.00876\left[\mathrm{SO}_{2}\right] \mathrm{Rh}_{60} \mathrm{e}^{\mathrm{fBr}(\mathrm{T})}+0.0409 \mathrm{Rn}\left[\mathrm{H}^{+}\right]\right. \\
\left.+0.038 \mathrm{PM}_{10}\right) \\
\mathrm{f}_{\mathrm{Br}}(\mathrm{T})=0.060(\mathrm{~T}-11) \text { when } \mathrm{T} \leq 11^{\circ} \mathrm{C} \\
\mathrm{f}_{\mathrm{B}} \mathrm{r}(\mathrm{T})=-0.067(\mathrm{~T}-11) \text { when } \mathrm{T}>11^{\circ} \mathrm{C}\end{array}$ & $\begin{array}{l}\text { Kucera et al. } \\
(2007)\end{array}$ \\
\hline & $\mathrm{R}_{\mathrm{Br}}=0.0255 \mathrm{R}_{\text {steel }}$ & $\begin{array}{l}\text { Noah's Ark } \\
(2006)\end{array}$ \\
\hline \multirow[t]{2}{*}{ Glass } & $\mathrm{LL}=0.013\left[\mathrm{SO}_{2}\right]^{0.49} \mathrm{Rh}^{2.8} t$ & $\begin{array}{l}\text { Tidblad et al. } \\
\text { (2001) }\end{array}$ \\
\hline & ${ }^{\mathrm{d}} \mathrm{LL}=-0.28+0.028 \mathrm{Rh}-0.055 \mathrm{~T}$ & $\begin{array}{l}\text { Noah's Ark } \\
\text { (2006) }\end{array}$ \\
\hline Lead & $\begin{array}{l}{ }^{\mathrm{b}} \mathrm{ML}=0.5\left(0.0125 \mathrm{D}_{\mathrm{Cl}}^{0.27} \mathrm{e}^{(0.036 \mathrm{Rh}+0.049 \mathrm{~T})}+\right. \\
0.0175 D_{\mathrm{Cl}}{ }^{0.57} \mathrm{e}^{(0.008 \mathrm{Rh}+0.085 \mathrm{~T})}\end{array}$ & $\begin{array}{l}\text { Noah's Ark } \\
(2006)\end{array}$ \\
\hline $\begin{array}{l}\text { Wood (Scots } \\
\text { pine sapwood } \\
\text { and Douglas fir } \\
\text { heartwood) }\end{array}$ & $\begin{array}{l}{ }^{e} d=d_{\mathrm{mc}} \times d_{\mathrm{t}} \\
d_{\mathrm{mc}}=6.75 \times 10^{-10} \mathrm{MC}^{5}-3.5 \times 10^{-7} \mathrm{MC}^{4}+7.18 \times 10^{-5} \mathrm{MC}^{3}- \\
7.22 \times 10^{-3} \mathrm{MC}^{2}+0.34 \mathrm{MC}-4.98(\text { if } \mathrm{MC}>25 \%) \\
d_{\mathrm{t}}=1.8 \times 10^{-6} \mathrm{~T}^{4}+9.57 \times 10^{-5} \mathrm{~T}^{3}-1.55 \times 10^{-3} \mathrm{~T}^{2}+4.17 \times 10^{-2} \\
\mathrm{~T} \text { (If } T_{\min }>-1^{\circ} \mathrm{C} \text { and } T_{\max }<40^{\circ} \mathrm{C}\end{array}$ & $\begin{array}{l}\text { Brischke and } \\
\text { Rapp (2008) }\end{array}$ \\
\hline
\end{tabular}


$1518{ }^{\mathrm{a}} t_{\mathrm{ow}}$ is the time of wetness i.e. fraction of exposure duration with temperature $>0{ }^{\circ} \mathrm{C}$ and $\mathrm{Rh}>80 \% ; u$ is 1519 the annual mean wind speed $\left(\mathrm{m} \mathrm{s}^{-1}\right)$ at $10 \mathrm{~m}$ above the ground level.

$1520{ }^{\mathrm{b}} D_{\mathrm{Cl}}$ is chloride deposition in $\mathrm{mg} \mathrm{m}^{-2} \mathrm{~d}^{-1}$.

$1521{ }^{\mathrm{c}}$ Gaseous and $\mathrm{PM}_{10}$ concentrations are annual mean in $\mathrm{mg} \mathrm{m}^{-3}$.

$1522{ }^{\mathrm{d}} \mathrm{LL}$ is in $\mu \mathrm{m}$.

$1523{ }^{\mathrm{e}} d$ is total daily dose, $d_{\mathrm{mc}}$ is moisture content (MC) induced daily dose and $d_{\mathrm{t}}$ is temperature induced 1524 daily dose; $T, T_{\min }$ and $T_{\max }$ are daily average wood temperature, minimum and maximum 1525 temperatures, respectively. These functions are developed up to 7 years exposure.

\begin{tabular}{|c|c|}
\hline Material & DRFs \\
\hline Carbon steel & $\begin{array}{l}\mathrm{r}_{\text {corr }}=1.77 \mathrm{P}_{\mathrm{d}}^{0.52} \mathrm{e}^{[0.020 \mathrm{Rh}+\mathrm{f}} \mathrm{St}^{]}+0.102 \mathrm{~S}_{\mathrm{d}}{ }^{0.62} \mathrm{e}^{[0.033 R h+0.040 \mathrm{~T}]} \\
\mathrm{f}_{\mathrm{St}}=0.150(\mathrm{~T}-10) \text { when } \mathrm{T} \leq 10^{\circ} \mathrm{C} \\
\mathrm{f}_{\mathrm{St}}=-0.054(\mathrm{~T}-10) \text { when } \mathrm{T}>10^{\circ} \mathrm{C}\end{array}$ \\
\hline Zinc & $\begin{array}{l}\mathrm{r}_{\text {corr }}=0.0129 \mathrm{P}_{\mathrm{d}}^{0.44} \mathrm{e}^{[0.046 \mathrm{Rh}+\mathrm{f}} \mathrm{Zn}^{\top}+0.0175 \mathrm{~S}_{\mathrm{d}}^{0.57} \mathrm{e}^{[0.008 \mathrm{Rh}+0.085 \mathrm{~T}]} \\
\mathrm{f}_{\mathrm{Zn}}=0.038(\mathrm{~T}-10) \text { when } \mathrm{T} \leq 10^{\circ} \mathrm{C} \\
\mathrm{f}_{\mathrm{Zn}}=-0.071(\mathrm{~T}-10) \text { when } \mathrm{T}>10^{\circ} \mathrm{C}\end{array}$ \\
\hline Copper & $\begin{array}{l}\mathrm{r}_{\text {corr }}=0.0053 \mathrm{P}_{\mathrm{d}}^{0.26} \mathrm{e}^{[0.059 \mathrm{Rh}+\mathrm{f}} \mathrm{Cu}^{1}+0.01025 \mathrm{~S}_{\mathrm{d}}^{0.27} \mathrm{e}^{[0.036 \mathrm{Rh}+0.049 \mathrm{~T}]} \\
\mathrm{f}_{\mathrm{Cu}}=0.126(\mathrm{~T}-10) \text { when } \mathrm{T} \leq 10^{\circ} \mathrm{C} \\
\mathrm{f}_{\mathrm{Cu}}=-0.080(\mathrm{~T}-10) \text { when } \mathrm{T}>10^{\circ} \mathrm{C}\end{array}$ \\
\hline Aluminium & $\begin{array}{l}\mathrm{r}_{\text {corr }}=0.0042 \mathrm{P}_{\mathrm{d}}^{0.73} \mathrm{e}^{[0.025 \mathrm{Rh}+\mathrm{f}} \mathrm{Al}^{\mathrm{j}}+0.0018 \mathrm{~S}_{\mathrm{d}}^{0.60} \mathrm{e}^{[0.020 \mathrm{Rh}+0.094 \mathrm{~T}]} \\
\mathrm{f}_{\mathrm{Al}}=0.009(\mathrm{~T}-10) \text { when } \mathrm{T} \leq 10^{\circ} \mathrm{C} \\
\mathrm{f}_{\mathrm{Al}}=-0.043(\mathrm{~T}-10) \text { when } \mathrm{T}>10^{\circ} \mathrm{C}\end{array}$ \\
\hline
\end{tabular}

Table 4. List of DRFs for calculation of the first-year corrosion loss of various structural metals, given by BS EN ISO 9223 (2012). Here, $r_{\text {corr }}$ is the first-year corrosion rate of metals in $\mu \mathrm{m} \mathrm{yr}^{-1}, T$ is the annual average temperature in ${ }^{\circ} \mathrm{C}, R h$ is the annual average relative humidity in $\%, P_{d}$ is the annual average $\mathrm{SO}_{2}$ deposition in $\mathrm{mg}$ $\mathrm{m}^{-2}$ day $^{-1}, S_{d}$ is the annual average $\mathrm{Cl}^{-}$deposition in $\mathrm{mg} \mathrm{m}^{-2}$ day $^{-1}$. 
1534 Table 5. Overview of climate change impacts on the structural integrity of built infrastructure.

\begin{tabular}{|c|c|c|c|c|c|}
\hline \multirow{2}{*}{$\begin{array}{l}\text { Climate change effect on } \\
\text { built infrastructure }\end{array}$} & \multicolumn{5}{|c|}{ Climate change variables } \\
\hline & Temperature & Precipitation & Humidity & Wind & $\begin{array}{l}\text { Sea level } \\
\text { rise }\end{array}$ \\
\hline $\begin{array}{l}\text { Building material } \\
\text { deterioration }\end{array}$ & $\otimes$ & $\otimes$ & $\otimes$ & & \\
\hline Building structural integrity & $\otimes$ & $\otimes$ & & $\otimes$ & $\otimes$ \\
\hline Building roofs & $\otimes$ & $\otimes$ & & $\otimes$ & \\
\hline Building foundations & $\otimes$ & $\otimes$ & & & \\
\hline $\begin{array}{l}\text { Bridge material } \\
\text { deterioration }\end{array}$ & $\otimes$ & $\otimes$ & $\otimes$ & & \\
\hline Bridge scour & & $\otimes$ & & & $\otimes$ \\
\hline Bridge thermal movements & $\otimes$ & & & & \\
\hline Bridge deck stability & & & & $\otimes$ & $\otimes$ \\
\hline $\begin{array}{l}\text { Bridge foundation } \\
\text { settlements/landslips }\end{array}$ & $\otimes$ & $\otimes$ & & & \\
\hline Pavement deterioration & $\otimes$ & $\otimes$ & $\otimes$ & & $\otimes$ \\
\hline Railway lines & $\otimes$ & $\otimes$ & & & $\otimes$ \\
\hline Highway / bridge drainage & $\otimes$ & $\otimes$ & & & \\
\hline Traffic signs/lighting & & & & $\otimes$ & \\
\hline Seaports & & & & $\otimes$ & $\otimes$ \\
\hline Airports & $\otimes$ & $\otimes$ & & & $\otimes$ \\
\hline Earthworks / embankments & $\otimes$ & $\otimes$ & & & \\
\hline Tunnels & & $\otimes$ & & & $\otimes$ \\
\hline Coastal defences & & & & & $\otimes$ \\
\hline
\end{tabular}

1536 Table 6. Summary of climate parameters and pollutant concentrations considered for estimating the deterioration of carbon steel during the period 2010-2090.

\begin{tabular}{cccccc}
\hline Year & $\begin{array}{c}{\left[\mathrm{SO}_{2}\right]} \\
\left(\mu \mathrm{g} \mathrm{m}^{-3}\right)\end{array}$ & $\begin{array}{c}\mathrm{Rh} \\
(\%)\end{array}$ & $\begin{array}{c}\mathrm{T} \\
\left({ }^{\circ} \mathrm{C}\right)\end{array}$ & $\begin{array}{c}\mathrm{Rn} \\
(\mathrm{mm})\end{array}$ & $\begin{array}{c}\mathrm{PM}_{10} \\
\left(\mu \mathrm{g} \mathrm{m}^{-3}\right)\end{array}$ \\
\hline 2010 & 17 & 78.9 & 11.2 & 643 & 30 \\
2030 & 15 & 78.4 & 11.8 & 643 & 15 \\
2050 & 14 & 77.7 & 12.5 & 645 & 14 \\
2070 & 13 & 77.0 & 13.3 & 645 & 13 \\
2090 & 12 & 76.6 & 14.0 & 646 & 12 \\
\hline
\end{tabular}




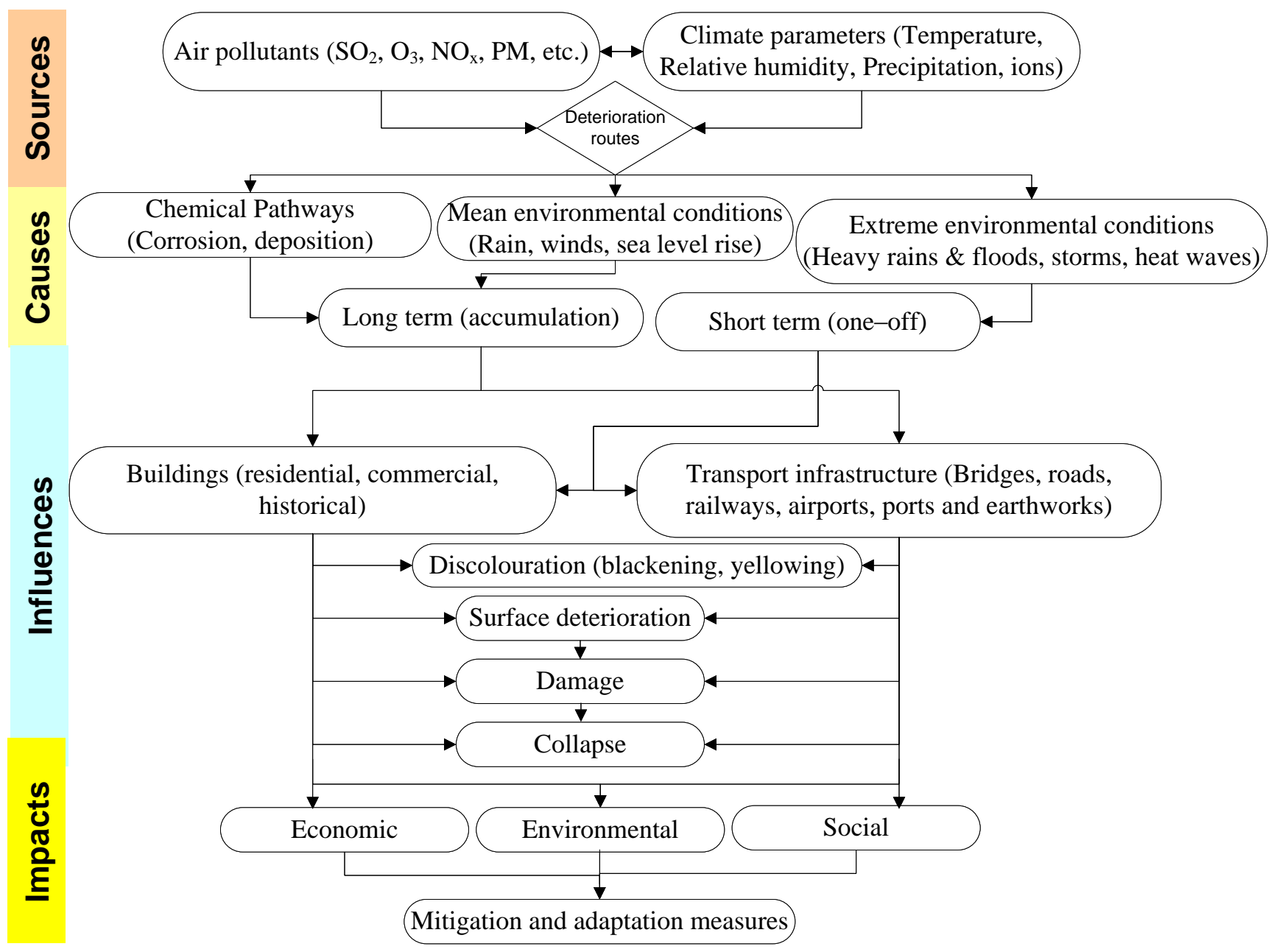




\section{Figure 2}

Click here to download Figure: Fig. 2.ppt_CO2 equivalent emissions.ppt

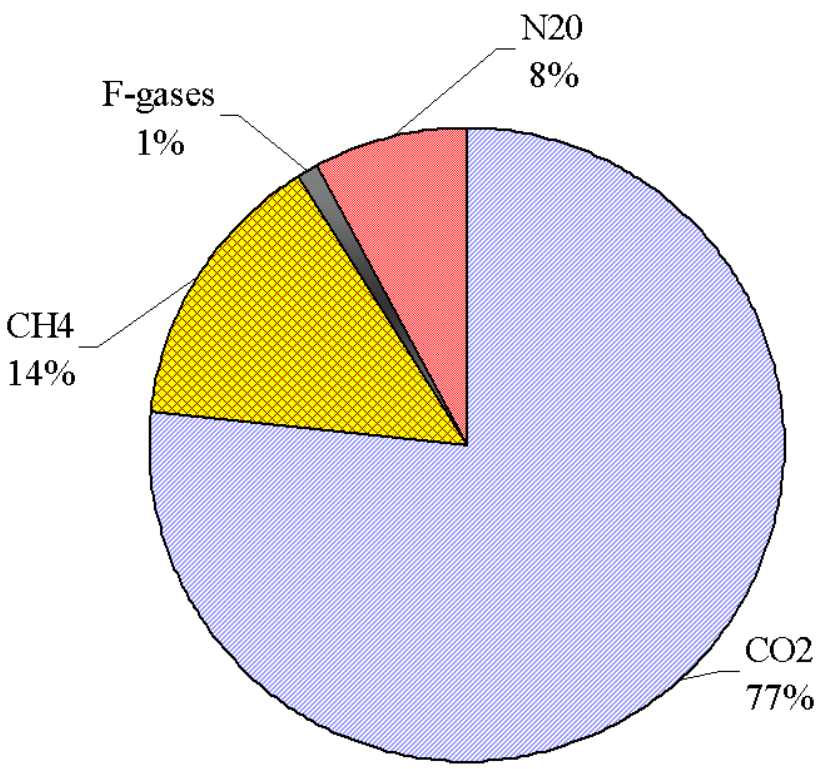

(a)

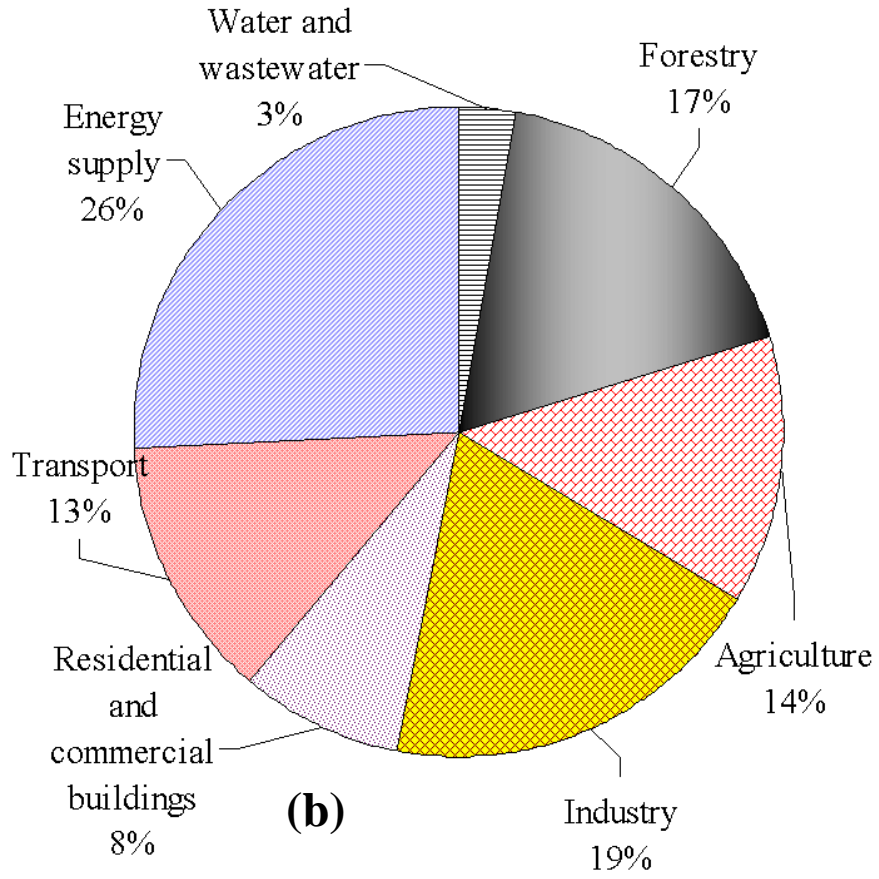



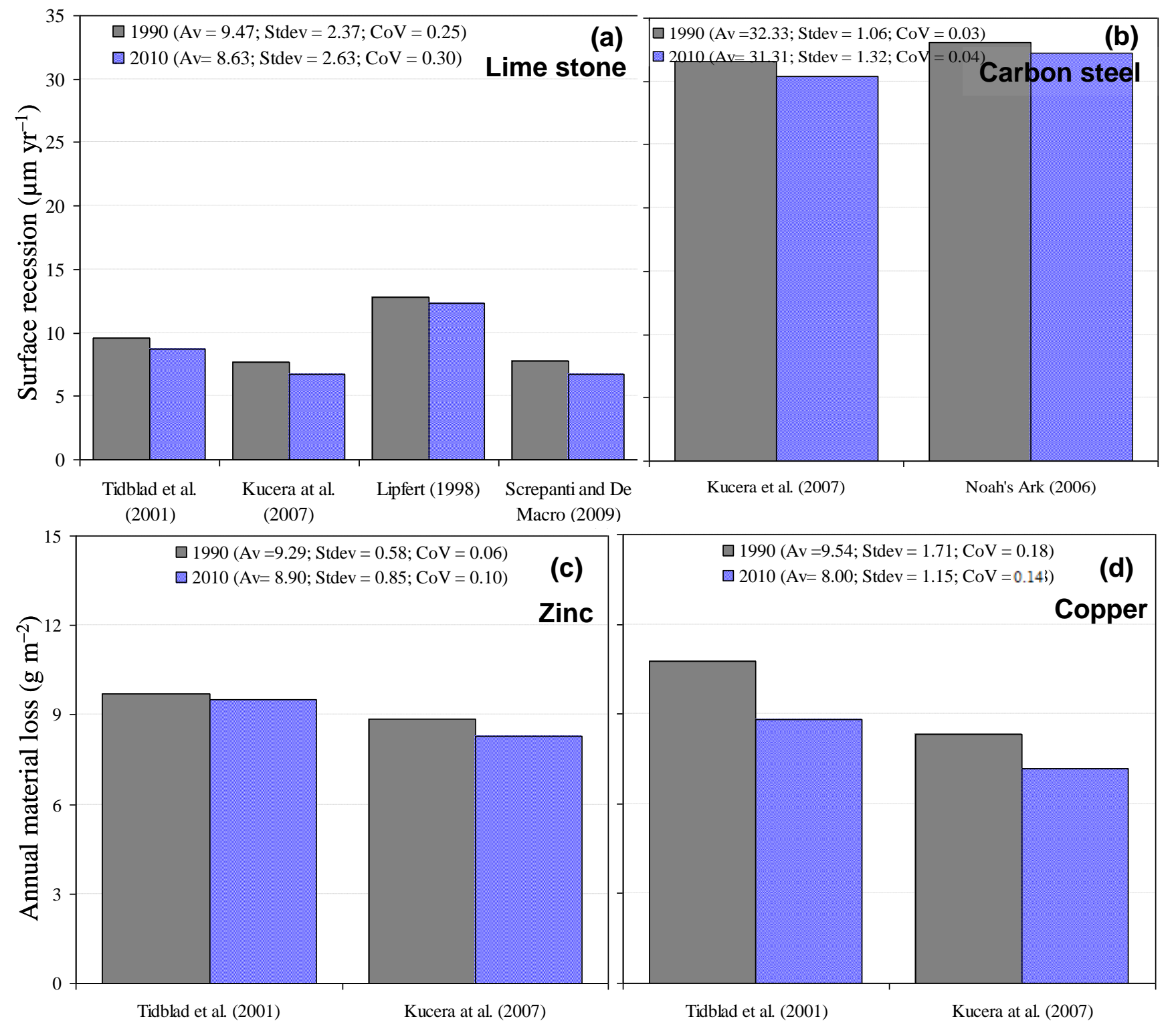
Click here to download Figure: Fig. 4.ppt_Carbon Steel_Case Study.pptx

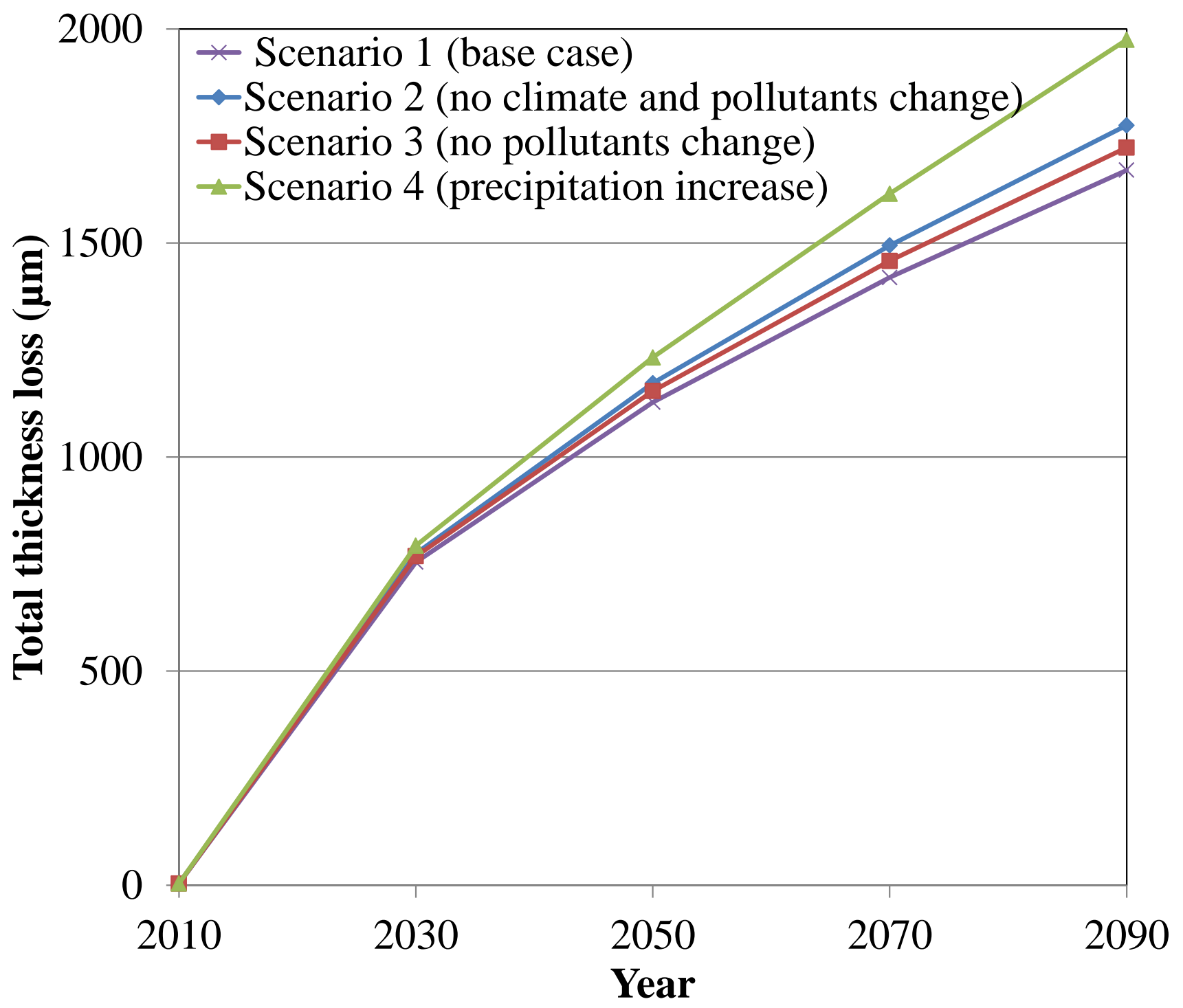




\section{Research Highlights}

- Impacts of air pollution and changing environment on built infrastructure is reviewed

Chemical sensitivity of various building materials is assessed

Inventory of DRFs, and their application through a case study, is carried out

Both air pollution and changing environment affect the integrity of built structures

Robust and generalised DRFs are needed for mapping corrosion losses accurately

Citation details:

Kumar, P., Imam, B. 2013. Footprints of air pollution and changing environment on the sustainability of built infrastructure. Science of the Total Environment 444, 85-101. http://dx.doi.org/10.1016/j.scitotenv.2012.11.056 